\title{
The Campo de Calatrava Volcanic Field (central Spain): Fluid geochemistry in a $\mathrm{CO}_{2}$-rich area
}

\author{
B. Nisi ${ }^{\mathrm{a}, *}$, O. Vaselli ${ }^{\mathrm{b}, \mathrm{c}}$, J. Elio ${ }^{\mathrm{d}}$, L. Giannini ${ }^{\mathrm{b}, \mathrm{c}}$, F. Tassi ${ }^{\mathrm{b}, \mathrm{c}}$, M. Guidi ${ }^{\mathrm{a}}$, T.H. Darrah ${ }^{\mathrm{e}}$, E.L. Maletic ${ }^{\mathrm{e}}$, \\ A. Delgado Huertas ${ }^{\mathrm{f}}$, S. Marchionni ${ }^{\mathrm{b}}$ \\ ${ }^{a}$ CNR- IGG (Institute of Geosciences and Earth Resources), G. Moruzzi, 1, 56124, Pisa, Italy \\ ${ }^{\mathrm{b}}$ Department of Earth Sciences, Via G. La Pira, 4, 50121, Florence, Italy \\ ${ }^{\mathrm{c}}$ CNR- IGG (Institute of Geosciences and Earth Resources), G. La Pira, 4, 50121, Florence, Italy \\ ${ }^{\mathrm{d}}$ ETS Ingenieros de Minas Universidad Politécnica de Madrid, Calle de Ríos Rosas, 21, 28003, Madrid, Spain \\ ${ }^{\text {e }}$ School of Earth Sciences, Ohio State University, 275 Mendenhall Laboratory, 125 South Oval Mall, Columbus, OH, 43210-1398, USA \\ ${ }^{\mathrm{f}}$ Instituto Andaluz de Ciencias de la Tierra, CSIC-UGR, Avda. de las Palmeras 4, Armilla, Spain
}

\section{A R T I C L E I N F O}

Editorial handling by Dr M Liotta

Keywords:

Campo de Calatrava volcanic field

Central southern Spain

$\mathrm{Mg}-\mathrm{HCO}_{3}$ waters

Geopressurized $\mathrm{CO}_{2}$-Rich reservoir

\begin{abstract}
A B S T R A C T
The Campo de Calatrava Volcanic Field (CCVF) located in central-southern Spain (along with Selva-Emporda in Catalonia, NE Spain) is regarded as one of the most important $\mathrm{CO}_{2}$ emitting zones in Peninsular Spain. Here, we report and evaluate new molecular and isotopic geochemistry of thermal waters and $\mathrm{CO}_{2}$-rich gas discharges from the CCVF. Locally, these $\mathrm{CO}_{2}$-rich fluid emissions represent the remnants of the past volcanic activity that affected this area from the late Miocene through the Quaternary, with the most recent events occurring in the Holocene. The locations of discharging fluids and previous volcanic centers appear to be aligned along welldefined NW-SE and NNW-SSE lineaments, with subordinate trends in the ENE-WSW direction. The chemical and isotopic composition of the thermal waters suggests a meteoric origin, dominated by three distinct geochemical facies: 1) $\mathrm{HCO}_{3}-\mathrm{Mg}(\mathrm{Ca})$ type waters, associated with a relatively shallow aquifer and related to the interaction of meteoric waters with $\mathrm{CO}_{2}$-rich gases, alkaline volcanic products, and sedimentary formations, 2) $\mathrm{SO}_{4}(\mathrm{Cl})-\mathrm{Ca}(\mathrm{Mg})$ type waters, which stems from the two rivers (Guadiana and Jabalón) that drain Triassic evaporitic rocks before entering the study area, and 3) $\mathrm{HCO}_{3}$-Na type waters, hosted in deep geopressurized $\mathrm{CO}_{2}$-rich reservoirs within the Ordovician basement rocks.

The ${ }^{87} \mathrm{Sr} /{ }^{86} \mathrm{Sr}$ isotopic compositions (ranging between 0.70415 and 0.71623$)$ and $\delta^{34} \mathrm{~S}_{-5 \mathrm{SO}_{4}}$ values $(+10.7$ to $+18.3 \%$ vs. $\mathrm{CDT}$ ) of $\mathrm{CO}_{2}$-rich fluids are consistent with interactions between water and either the Paleozoic basement, Triassic evaporites, Quaternary volcanic rocks, or a combination thereof. Dissolution of a $\mathrm{CO}_{2}$-rich gas phase into the aquifer produces low $\mathrm{pH}$ values (down to 5.4) and enhances water-rock interactions causing relatively high salinity (Total Ionic Salinity: up to $\sim 185 \mathrm{meq} / \mathrm{L}$ ). Carbon dioxide is by far the most abundant gas constituent (up to $992 \mathrm{mmol} / \mathrm{mol}$ ) and is dominated by mantle-derived sources as indicated by the combination of relatively high helium isotopic ratios (up to $2.7 \mathrm{R} / \mathrm{Ra}$ ), high isotopic ratios of carbon in $\mathrm{CO}_{2}$ (ranging between -6.8 and $-3.2 \%$ V-PDB), and the carbon isotopic signature of TDIC (from -6.8 to $+2.2 \%$ o $v$. VPDB).

In the last two decades, numerous $\left(\mathrm{CO}_{2}\right.$-rich) gas blowouts have occurred in the area during well drillings, suggesting the presence of a geopressurized gas reservoir at relatively shallow depth.
\end{abstract}

\section{Introduction}

There are four areas of Neogene volcanic activity in continental Spain, including the Internal Betics (SE Spain; 34-2 Ma), the Valencia Trough (24-0.01 Ma), the Calatrava Volcanic Province (9-0.7 Ma), and Olot-Garrotxa (10-0.01 Ma). A fifth area of Late Miocene (12.1-6.1 Ma) volcanic activity is present in the Alboran Basin (westernmost
Mediterranean Sea between the southern coast of Spain and northern Morocco) where dacites, rhyolites, and granites occur with significant volumes of tholeiitic to calc-alkaline basalts, basaltic andesites, and andesites (e.g. Duggen et al., 2004, 2005 and references therein) (Fig. 1).

Out of these five volcanic fields, three areas exhibit $\mathrm{CO}_{2}$-rich gas emissions. The majority of $\mathrm{CO}_{2}$ emissions is associated with low-

\footnotetext{
* Corresponding author. CNR-IGG Institute of Geosciences and Earth Resources, Via Moruzzi, 1, 56124, Pisa, Italy.

E-mail address: b.nisi@igg.cnr.it (B. Nisi).
} 


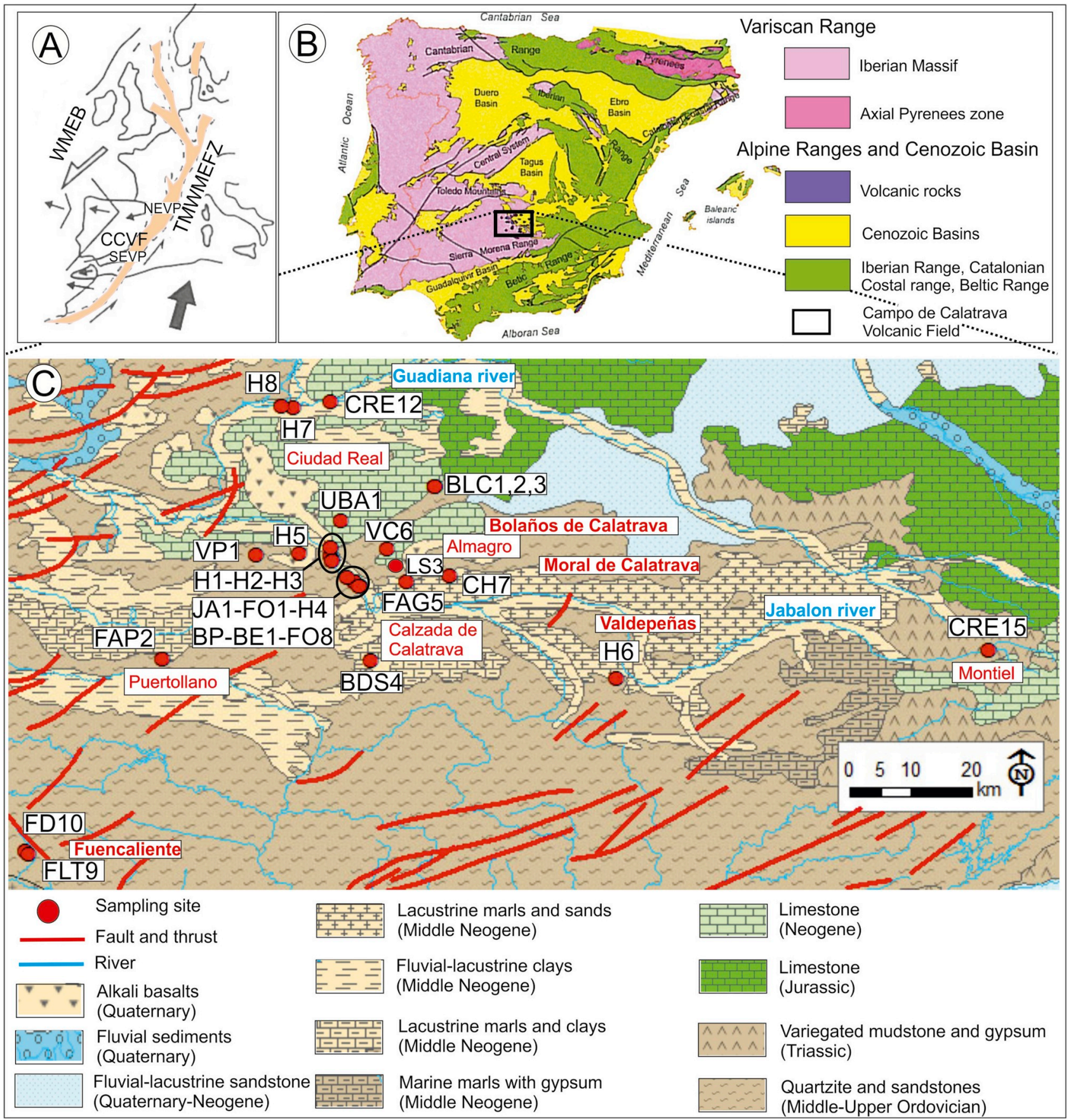

Fig. 1. a) Location of the Trans-Moroccan, Western Mediterranean, European Fault Zone (TMWMEFZ, López Ruiz et al., 2002), the Campo de Calatrava Volcanic Field (CCVF), and the Western Mediterranean European Block (WMEB); b) Schematic geological map of the Iberian Peninsula and c) Map of the Calatrava Volcanic Field with the locations of sampled waters (by ${ }^{\circledR}$ National Geographic Institute: IGN; http://www.ign.es/wms-inspire/pnoa-ma).

thermal waters and occurs in areas with recent volcanic activity. Prominent $\mathrm{CO}_{2}$ gas discharges are recognized at: 1) Olot-Garrotxa (in the NE Volcanic Province, hereafter NEVP), 2) the Internal Betics (in the SE Volcanic Province, hereafter, SEVP), and 3) Campo de Calatrava (south-central Spain, Volcanic Field, hereafter, CCVF) (Fig. 1A). These volcanic provinces are likely part of an aborted rift, which is most clearly expressed in the Rhine Valley, and lie along the Trans-Moroccan Western Mediterranean-European Fault Zone (TMWMEFZ, Fig. 1A; e.g. López-Ruiz et al., 2002). While the NEVP and CCVF are dominantly characterized by alkaline basaltic volcanism (e.g. Cebriá and LópezRuiz, 1995; Cebriá et al., 2000), the SEVP displays calc-alkaline, high-K calc-alkaline, shoshonitic, ultrapotassic, and alkaline basaltic volcanics
(Duggen et al., 2005; Cebriá et al., 2009). In the CCVF, minor LateMiocenic volcanic episodes (8.7-6.4 Ma) of leucititic eruptions were followed by alkali basalts, basanites, ol-nephelinites, melitites, and carbonatites in the Pliocene-Quaternary during which diatremes and maars formed (López-Ruiz et al., 1993; Ancochea, 2004; Bailey et al., 2005). Most volcanic deposits contain mantle xenoliths sourced from depths of $>70 \mathrm{~km}$ (e.g. Bianchini et al., 2010; Martelli et al., 2011).

Most CCVF volcanoes intruded the Palaeozoic basement in the Calatrava and Almagro massifs, the latter showing E-W and N-S vertical, flexural folds (De Vicente et al., 2007). Such massifs are affected by NW-SE and E-W-oriented fault systems to produce a horst and graben morphology (e.g. Stoppa et al., 2012), along which the main 
$\mathrm{CO}_{2}$-rich gas emissions are found (Poblete Piedrabuena, 1997; González Cárdenas and Gosálvez Rey, 2004).

In this work, we examine thermal waters and gas discharges from the Campo de Calatrava Volcanic Field, where in the last few decades the presence of a $\mathrm{CO}_{2}$-pressurized reservoir at a relatively shallow depth in this region has caused several small-sized explosions or gas blowouts, particularly during the drilling (down to $200 \mathrm{~m}$ ) of domestic water wells (e.g. González Cárdenas et al., 2015). The main objectives of this investigation are to i) describe the geochemical and isotopic features of the thermal water and gas discharges in the CCVF from samples collected in July 2009 and July 2012; ii) determine if the root of mantlederived volcanism that led to the formation of the CCVF is still present and actively communicating with the surface, and iii) provide a conceptual model based on the available geochemical and isotopic data.

\section{Geological and volcanological setting}

During the last $60-70$ million years, the areas in and around the Mediterranean Sea have experienced extensive igneous activity (e.g. Wilson and Downes, 1991). The Campo de Calatrava Volcanic Field (CCVF) is one of the main Cenozoic magmatic provinces belonging to the circum-Mediterranean region (Lustrino and Wilson, 2007). The volcanic activity in this area has variably been attributed to either small mantle plume/hot spots (Cebriá and López Ruiz, 1995; Wilson and Patterson, 2001; Bell et al., 2013) or the complex Trans-Moroccan Western Mediterranean-European Fault Zone (TMWMEFZ, López Ruiz et al., 2002), the latter likely being generated by a large asymmetric mantle upwelling related to the former North America-South AmericaAfrica triple junction (Oyarzun et al., 1997).

From the Miocene to present, alkaline basaltic volcanism occurred within and is likely associated with TMWMEFZ (López Ruiz et al., 2002). The TMWMEFZ offers a peculiar tectono-magmatic scenario that extends from the northern Europe through the Alpine arc to the Pyrenees (López Ruiz et al., 2002; Doblas et al., 2007) (Fig. 1A) and bounds the west-directed Western Mediterranean European Block (WMEB; López Ruiz et al., 2002). The current understanding suggests that CCVF is an expression of lateral extension of the TMWMEFZ along the edge of the Central Iberian Zone of the Iberian Massif, close to the outer sectors of the Alpine Betic Range (Fig. 1B).

The geology of the study area includes Paleozoic basement rocks covered by late Cenozoic sediments. The Paleozoic rocks are mainly quartzites belonging to the so-called Armorican facies (lower Ordovician), which are overlain by slates, sandstone interbeds, and discontinuous carbonate (upper Ordovician) deposits that are folded from NW-SE to W-E (López-Ruiz et al., 1993; Gutiérrez-Marco et al., 2002). Extensive outcrops of Triassic rocks occur in the eastern portion of the CCVF, including the Germanic facies (Buntsandstein, Muschelkalk, and Keuper). Upper Miocene to Quaternary fluvial and lacustrine sediments were deposited within fault-bounded Tertiary-Quaternary basins related to the Late Miocene extensional tectonic activity, and unconformably overlie the basement rocks (Fig. 1C) (Ancochea and Brändle, 1982; López Ruiz et al., 1993, 2002; Cebriá and López Ruiz, 1995; Carracedo Sánchez et al., 2012; Herrero-Hernández et al., 2015).

The CCVF was the primary location for late Miocene-Quaternary volcanic activity in central Spain (Fig. 1C). Vents and outcrops of mafic lava flows and pyroclastic deposits of alkaline composition are scattered throughout the area, which cover approximately $5000 \mathrm{~km}^{2}$ (e.g., Ancochea, 1999; Gonzalez Cardenás et al., 2007; Stoppa et al., 2012).

The CCVF volcanic rocks are part of an intracontinental plate magmatic association (Cebria and Lopez-Ruiz, 1995; López-Ruiz et al., 1993; 2002) consisting of mafic silica-undersaturated alkaline lavas (from alkali basalts and nephelinites to melilitites and leucitites) (Cebrià and Lopez- Ruiz, 1995; López-Ruiz et al., 1993, 2002; Stoppa et al., 2012) which commonly host mantle xenoliths (Martelli et al., 2011 and references therein) and carbonatites (Bailey et al., 2005, Humphreys et al., 2010; Stoppa et al., 2012). The CCVF volcanics display a close affinity to the Miocene-Quaternary volcanic regions of western and central Europe (Wilson and Downes, 1991). Trace element geochemistry displays enrichments of incompatible elements that were interpreted as a mixture of lithospheric and asthenospheric mantle (with affinities to a HIMU-OIB source mantle), which experienced a small degree of partial melting (e.g. Cebrià and Lopez-Ruiz, 1995; Martelli et al., 2011).

The main eruptive features that characterized the CCVF were dominantly caused by strombolian-type and hydromagmatic eruption events (Ancochea, 1999; Gonzalez Cardenás et al., 2007, 2010; Stoppa et al., 2012; Becerra-Ramírez et al., 2010; Stoppa F. and Schiazza M., 2013) without any reported evidence of hawaiian-type eruptions (Ancochea, 1999), contradicting what was reported by Carracedo Sànchez et al. (2009). The hydromagmatic eruptions play a key role in the volcanological history of CCVF, since most volcanic centers show deposits related to interactions between magma and water. Occasionally, hydromagmatic products alternate with those related to strombolian-type eruptive activity. The crater bottoms have often developed endorheic or subendorheic areas, where small evaporitic deposits are also found (Ancochea, 1999). The CCVF can be subdivided into two phases (Ancochea, 1982, 1999) based on the age and composition of the volcanic products. The first phase, which consists of ultrapotassic volcanics is less intense and occupies the central part of the region. Radiometric ages suggest that the emplacement of these volcanics occurred between 8.7 and 6.4 Ma. The second phase, which includes alkaline and ultra-alkaline volcanics, was emplaced between 3.7 and $0.7 \mathrm{Ma}$. The best preserved volcanic edifices are synchronous and successive to the detritic-carbonate deposit of the Upper Pliocene (Portero et al., 1984). In the central part of the region (Ciudad Real and Almagro) the Plio-Pleistocene erosional surface is intruded and deformed by several volcanic centers. Note that Gonzáles Cárdenas et al. (2007) attributed an age of 5550 BP to Columba volcano, which is located about $8 \mathrm{~km}$ south of La Sima (Fig. 1C).

The CCVF is characterized by a complex fracture pattern that controls the geometries of the E-W to ENE-WSW, NW-SE, and NE-SW basins (Crespo, 1992), as well as the facies and thickness of the Cenozoic continental sediments. In addition to the Late Miocene extensional phase, at least two Neogene tectonic episodes in the CCVF took place: (i) the opening of the La Mancha Basin and (ii) a weak regional-scale compressional phase (IGME, 1988). Consequently, the region shows a basin and range-like morphology. The ranges are relatively high with elevations between 700 and $900 \mathrm{~m}$ and highlands with an elevation of approximately $600 \mathrm{~m}$. The Guadiana River and the Jabalón River, which is the main tributary to the Guadiana River in its upper reaches, are the two main rivers that drain the study area. Both rivers have a roughly NS and NW-SE-orientation, respectively (Poblete Piedrabuena et al., 2016) and interact with extensive evaporitic outcrops of Triassic age before flowing through the CCVF.

\section{Thermal waters and $\mathrm{CO}_{2}$-rich emissions}

The CCVF has a complex and intriguing volcanic and tectonic setting, which in combination with that of Selva-Empordá, accounts for the majority of natural $\mathrm{CO}_{2}$ emissions within Peninsular Spain (Catalonia; e.g. Vaselli et al., 2013; Elio et al., 2015 and references therein). As mentioned, the CCVF is a relatively young volcanic field and hosts a large number of springs. Both are regarded as an economic/ touristic resource for the region (Escobar and González, 2010; BecerraRamírez et al., 2017).

The thermal springs are often accompanied by $\mathrm{CO}_{2}$-rich gas bubbling pools, locally known as "hervideros" (e.g. Yélamos et al., 1999; Melero Cabañas, 2007), and $\mathrm{CO}_{2}$-rich dry gas vents (e.g. Peréz et al., 1996; Melero Cabañas, 2007; Vaselli et al., 2011, 2012). The manifestations of the CCVF are primarily located in the southern sub-plateau of the Castilla-La Mancha region and are aligned with well-defined lineaments that trend NW-SE, NNW-SSE, and subordinately ENE-WSW 

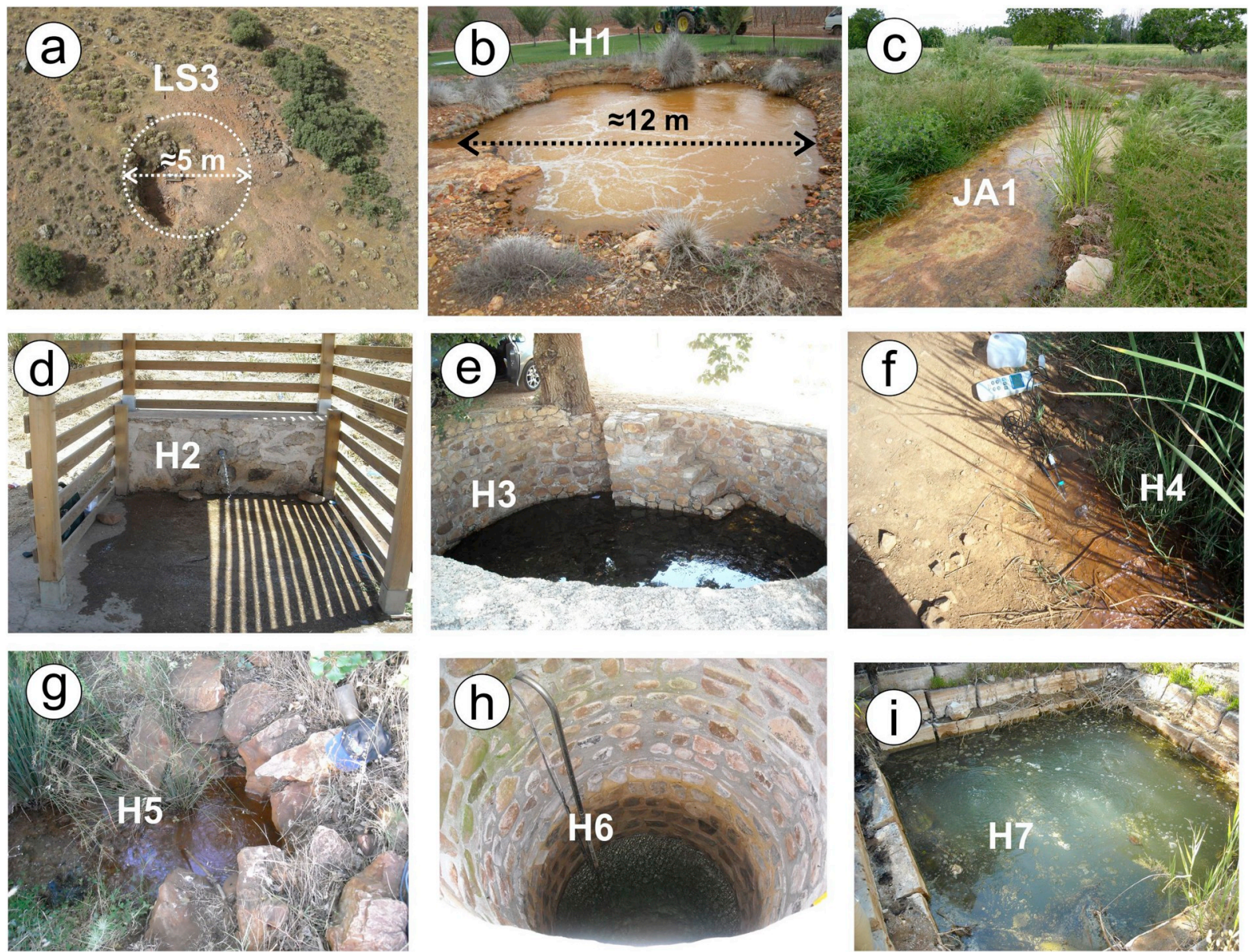

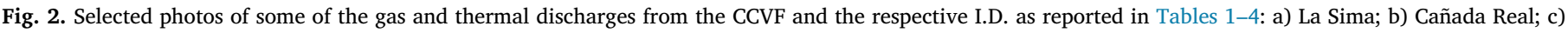
Javalon; d) Fuente Gallega; e) El Chorillo; f) El Baño Chico; g) Los Baños de Villa Franca; h) Balneares Cervantes; i) Baño del Trujillo.

(Melero Cabañas, 2007). Locally, the surface $\mathrm{CO}_{2}$-rich emissions are mainly associated within zones of more intense fracture systems and are commonly found as small $\left(<1 \mathrm{~m}^{2}\right)$ emission sites. The gas emission rate ranges from barely observable gentle bubbling to intense and vigorous fluxes of $\mathrm{CO}_{2}$. Among the $\mathrm{CO}_{2}$ emissions in the area, La Sima (dry gas vents, Fig. 2a), Cañada Real (degassing pools, Fig. 2b), and Jabalón River (degassing pools and springs, Fig. 2c) can be considered the three most representative sites of the $\mathrm{CO}_{2}$ seepage in the CCVF.

La Sima is a $\mathrm{CO}_{2}$-rich gas discharge (up to 2 tons of $\mathrm{CO}_{2}$ per day) that emits from a restricted surface depression of approximately $5 \mathrm{~m}$ in diameter (Fig. 2a) (Elio et al., 2015), where numerous small dead animals such as lizards, mice, and birds are found. The Cañada Real discharge (Vaselli et al., 2013; Gasparini et al., 2016) is located in the wine yard of the homonymous farmhouse (Municipality of Pozuelo de Calatrava). The Cañada Real consists of two pools: the smaller one is about $2 \mathrm{~m}$ wide while the larger one is approximately $12 \mathrm{~m}$ in diameter (Fig. 2b). The larger pool is characterized by intense gas bubbling with an estimated $\mathrm{CO}_{2}$ emission rate between 5 and 20 tons/day, with a mean value of 10 tons/day (Vaselli et al., 2012). The Jabalón River discharge is located $6 \mathrm{~km}$ from the village of Granátula de Calatrava (Fig. 2c), where moderate to large $\mathrm{CO}_{2}$-rich emissions (estimated discharge rate: 10 tons/day, Vaselli et al., 2012) bubble into $<30^{\circ} \mathrm{C}$ waters, although the highest recorded temperature in the area is the spa at Baños de Fuencaliente $\left(38^{\circ} \mathrm{C}\right.$; e.g. Poblete Piedrabuena, 1992) whose access was prevented by the owners. Most thermal discharges are aligned along a NW-SE fault system that runs parallel to the Jabalón River.

Remarkably, numerous high-pressure gas discharge blasts (commonly termed blowouts) have been reported to occur in the CCVF due to water well drilling in the region. One of the most famous occurrences is the "El Chorro" geyser in the Granátula-Moral de Calatrava (Fig. 1C) that discharged from a $200 \mathrm{~m}$ deep well and blasted a column of water and gas up to $60 \mathrm{~m}$ into the area during drilling operations in 2000 (González Cárdenas et al., 2015). The most recent significant event took place in 2011 (close to the Yesosa volcano, Almagro, Fig. 1C). This discharge, named the "geyser" of Bolaños de Calatrava, spontaneously appeared in a vineyard and produced approximately $50,000 \mathrm{~m}^{3}$ of water propelled by gases that covered an area of about $90,000 \mathrm{~m}^{2}$ and discharged up to 40 tons of carbon/day as $\mathrm{CO}_{2}$ for several days (Vaselli et al., 2012; Stoppa et al., 2012; González Cárdenas et al., 2015). Minor "eruptive" events were recorded to the SW and E of Almagro at Aldea del Rey and Calzada de Calatrava and Hoya del Peral, El Barranco and Lo Oscuro (in 2011), and El Prado (in 2013), respectively (González Cárdenas et al., 2015). Furthermore, after the seismic crisis that occurred in 2007 , a significant increase in gas emission rates (from 0.03 up to $324 \mathrm{~kg} / \mathrm{m}^{2} /$ day) was registered at La Sima where new $\mathrm{CO}_{2}$-rich gas vents also opened (González Cárdenas et al., 2007; Peinado et al., 2009).

These events are strongly indicative of a geologically pressurized $\left(\mathrm{CO}_{2}\right.$-rich) reservoir (estimated at about 63 bars during the Bolaños de Calatrava gas blast) that occurred at shallow depths in this region (González Cárdenas et al., 2015). The occurrence of spontaenous gas discharges/blowouts suggests that this area is "overpressured," meaning naturally occurring geological pressures exceed the anticipated hydrostatic pressure gradient. 


\section{Materials and methods}

\subsection{Sampling}

Between July 2009 and July 2012, 28 samples were collected throughout the Campo de Calatrava Volcanic Field that included thermal and cold waters, surface waters, dissolved gas samples, and free gas samples. The sampling site locations are shown in Fig. 1C. Samples were collected from (i) 7 bubbling pools $(\# \mathrm{H} 1, \# \mathrm{H} 3$, \#H3b, \#H7, \#VP1, \#BDS4, and \#FO8); (ii) 9 spring discharges (\#H2, \#FAG5, \#VC6, \#CH7, \#UBA1, \#FO1, \#BE1, \#FD10, and \#FLT9); (iii) 3 groundwater upwelling (\#BLC1, \#BLC2, and \#BLC3); (iv) 3 gas-rich springs (\#H4, \#H5, and \#FAP2); (v) 3 rivers (\#H8, \#CRE12, and \#CRE15); (vi) 1 river with bubbling gas (\#JA1); (vii) 1 water well with bubbling gas (\#H6), and (viii) 1 dry vent (\#LS3). Water and the associated gas from \#H1 (Cañada Real) were sampled and analyzed twice (July 2009 and May 2012). During the first sampling, water and gas were collected from the small pool since the big pool at that time was not accessible. Consequently, the big pool was collected during the second sampling trip. Selected images of the dry vents of La Sima (\#LS3), the bubbling pool of Cañada Real (\#H1), the Jabalón River (\#JA1), Fuente Gallega (\#H2), El Chorillo and El Baño Chico (\#H3 and \#H4, respectively), Los Baños de Villa Franca and Balneares Cervante (\#H5 and \#H6, respectively), and El Baño del Trujillo (\#H7) are reported in Fig. 2a-i.

\subsection{Chemical and isotopic analysis of water samples}

Temperature, $\mathrm{pH}$, electric conductivity, and alkalinity (titration with $0.01 \mathrm{~N} \mathrm{HCl}$ and methyl-orange as the indicator) were determined in the field following standard methods. Water samples were filtered $(0.45 \mu \mathrm{m})$ and stored in high-density polyethylene bottles for laboratory analyses. Cations $\left(\mathrm{Ca}^{2+}, \mathrm{Mg}^{2+}, \mathrm{Na}^{+}\right.$, and $\left.\mathrm{K}^{+}\right)$and anions $\left(\mathrm{Cl}^{-}, \mathrm{SO}_{4}{ }^{2-}\right.$, $\mathrm{F}^{-}, \mathrm{Br}^{-}$, and $\mathrm{NO}_{3}{ }^{-}$) were analyzed by using AAS (AAnalyst 100 Perkin Elmer) and Ion Chromatography (Dionex 100) on filtered and acidified ( $0.5 \mathrm{~mL}$ Suprapur $\mathrm{HCl}$ were added to $50 \mathrm{~mL}$ of water) bottles for cations and on filtered only samples for anions, respectively, following methods reported previously (Cuoco et al., 2013; Nisi et al., 2013a). Ammonia $\left(\mathrm{NH}_{4}{ }^{+}\right)$was analyzed by molecular spectrophotometry following methods reported previously (Hach DR2100). Trace elements (Al, As, $\mathrm{Ba}, \mathrm{B}, \mathrm{Cs}, \mathrm{Co}, \mathrm{Cr}, \mathrm{Cu}, \mathrm{Fe}, \mathrm{Hg}, \mathrm{Li}, \mathrm{Mn}, \mathrm{Rb}, \mathrm{Se}, \mathrm{Sr}$, and $\mathrm{Zn}$ ) were determined on filtered and acidified $\left(0.5 \mathrm{~mL}\right.$ Suprapur $\mathrm{HNO}_{3}$ were added to $50 \mathrm{~mL}$ of water) samples by ICP-MS by methods reprorted previously. The analytical error for major and trace compounds was $<5$ and $10 \%$, respectively.

Four aliquots for each water were sampled for the isotopic analysis, as follows: (i) $125 \mathrm{~mL}$ for oxygen and hydrogen in $\mathrm{H}_{2} \mathrm{O}$; (ii) $50 \mathrm{~mL}$ for carbon in TDIC (Total Dissolved Inorganic Carbon) after adding approximately $2 \mathrm{mg}$ of $\mathrm{HgCl}_{2}$ to inhibit carbon isotopic fractionation by bacteria (Atekwana and Krishnamurthy, 1998); (iii) $125 \mathrm{~mL}$ with bottles pre-cleaned with sub-boiled $\mathrm{HCl} 6 \mathrm{~N}$ for $\mathrm{Sr}$ dissolved concentrations and ${ }^{87} \mathrm{Sr} /{ }^{86} \mathrm{Sr}$ isotopic ratios; and (iv) $500 \mathrm{~mL}$ for sulfur isotopes in $\mathrm{SO}_{4}$.

The ${ }^{18} \mathrm{O} /{ }^{16} \mathrm{O}$ and ${ }^{2} \mathrm{H} /{ }^{1} \mathrm{H}$ isotopic ratios (expressed as $\delta^{18} \mathrm{O}$ and $\delta \mathrm{D} \%$ vs. VSMOW) were determined by using a Finnigan MAT 250 Delta-S mass spectrometer using standard procedures (Doveri and Mussi, 2014). The analytical precision was $0.1 \%$ for $\delta^{18} \mathrm{O}$ and $1 \%$ or for $\delta \mathrm{D}$. Carbon isotopes in TDIC (expressed as $\delta^{13} \mathrm{C} \%$ vs. VPDB) were performed with a Finnigan Delta Plus XL mass spectrometer on the $\mathrm{CO}_{2}$ recovered after the reaction of about $3 \mathrm{~mL}$ of water with $2 \mathrm{~mL}$ of anhydrous $\mathrm{H}_{3} \mathrm{PO}_{4}$ in $12 \mathrm{~mL}$ pre-evacuated vials (Salata et al., 2000). The recovered $\mathrm{CO}_{2}$ was analyzed after extraction and purification procedures on the gas mixture were performed using liquid $\mathrm{N}_{2}$ and a solidliquid mixture of liquid $\mathrm{N}_{2}$ and trichloroethylene (e.g. Vaselli et al., 2006, 2009). The analytical error for $\delta^{13} \mathrm{C}$-TDIC was \pm 0.05 .

The ${ }^{34} \mathrm{~S} /{ }^{32} \mathrm{~S}$ ratios of $\mathrm{SO}_{4}{ }^{2-}$ (expressed as $\delta^{34} \mathrm{~S}-\mathrm{SO}_{4} \%$ vs. V-CDT) for seven selected water samples were analyzed using an EA-IRMS (Europa
Scientific, Crewe, UK), equipped with an elemental analyzer (Sercon Ltd., Crewe, UK), after the precipitation of $\mathrm{BaSO}_{4}$ with $\mathrm{BaCl}_{2}$. After centrifugation and drying, the solid phase was transferred into tin capsules with a $\mathrm{V}_{2} \mathrm{O}_{5}$ catalyst. The capsules were loaded in sequence into a furnace at $1080^{\circ} \mathrm{C}$ using an automatic sampler and combusted in the presence of $\mathrm{O}_{2}$. Next, the temperature was increased to $1700^{\circ} \mathrm{C}$. The combusted gases were then swept in a helium stream over combustion catalysts (tungsten oxide/zirconium oxide) and through a reduction stage of high purity copper wires to produce $\mathrm{SO}_{2}, \mathrm{~N}_{2}, \mathrm{CO}_{2}$, and water. Water was removed using a Nafion ${ }^{\mathrm{TM}}$ membrane and $\mathrm{SO}_{2}$ was resolved from $\mathrm{N}_{2}$ and $\mathrm{CO}_{2}$ on a packed GC column at $45^{\circ} \mathrm{C}$. The resultant $\mathrm{SO}_{2}$ peak entered the ion source of the IRMS. Gas species of different mass were separated in a magnetic field and simultaneously measured on a Faraday cup universal collector array. Analysis was based on monitoring of $m / z 48,49$, and 50 of $\mathrm{SO}^{+}$produced from $\mathrm{SO}_{2}$ in the ion source. Reference standards (IA-R025, IA-R026, and IA-R061) were used for calibration and correction of the ${ }^{18} \mathrm{O}$ contribution to the $\mathrm{SO}^{+}$ ion beam while working standards were NBS-127, IAEA-SO-5, and IAEA-S-1. The analytical uncertainly was $\pm 0.3 \%$.

The ${ }^{87} \mathrm{Sr} /{ }^{86} \mathrm{Sr}$ isotopic ratios of six selected water samples were measured in a dynamic mode with a nine-collector Finnigan Triton-TI mass spectrometer (Avanzinelli et al., 2005) using the procedures described in Nisi et al. (2008). External precision of NIST SRM987 international reference sample for period of this study was ${ }^{87} \mathrm{Sr} /{ }^{86} \mathrm{Sr}=0.710246 \pm 0.000005(2 \sigma, \mathrm{n}=40)$, while the long-term mean value was $0.710248 \pm 0.000015(2 \sigma, \mathrm{n}=186)$.

Finally, $\mathrm{pCO}_{2}$, saturation index (SI), and TDIC were computed by means of the EQ3 code (Wolery and Jarek, 2003).

\subsection{Chemical and isotopic analysis of dissolved and free gas samples}

The dissolved gases were collected in pre-evacuated $250 \mathrm{~mL}$ glass flasks tapped with Teflon stopcocks according to the procedure reported in Tassi et al. (2008, 2009). The determination of dissolved gases was carried out at equilibrium conditions (STP, Standard Temperature and Pressure). The dissolved inorganic gases in the headspace of the sampling flasks $\left(\mathrm{CO}_{2}, \mathrm{~N}_{2}, \mathrm{Ar}, \mathrm{O}_{2}, \mathrm{Ne}, \mathrm{He}\right.$, and $\left.\mathrm{H}_{2}\right)$ were measured by gas chromatography with a Shimadzu $15 \mathrm{~A}$ equipped with a $5 \mathrm{~m}$ long stainless-steel column packed with Porapak 80/100 mesh and a Thermal Conductivity Detector (TCD), with the exception of $\mathrm{Ar}$ and $\mathrm{O}_{2}$ since a Thermo Focus gas chromatograph equipped with a $30 \mathrm{~m}$ long capillary molecular sieve column was used. $\mathrm{CH}_{4}$ was analyzed using a Shimadzu 14A equipped with a $10 \mathrm{~m}$ long stainless-steel column packed with Chromosorb PAW 80/100 mesh coated with 23\% SP 1700 and a Flame Ionization Detector (FID) (e.g. Vaselli et al., 2006; Tassi et al., 2018). The analytical error for GC analysis was $\leq 5 \%$. The gas species in the liquid phase were calculated according to the Henry's Law constants (Wilhelm et al., 1977).

Gas samples from bubbling pools were collected using pre-weighted and pre-evacuated $50 \mathrm{~mL}$ thorion-tapped glass tubes, partially filled with $20 \mathrm{~mL}$ of $4 \mathrm{~N} \mathrm{NaOH}$ connected to a plastic funnel positioned over the rising bubbles (Montegrossi et al., 2001; Vaselli et al., 2006). Acidic gases (e.g. $\mathrm{CO}_{2}$ and $\mathrm{H}_{2} \mathrm{~S}$ ) dissolved in the alkaline solution where the residual gases enriched in the glass tube headspace. The chemical gas composition in the gas vial headspace was determined by gas-chromatography, while gas concentrations in the liquid phase were determined by ion-chromatography (Tassi et al., 2004, 2009; Vaselli et al., 2006). A second group of pre-evacuated $50 \mathrm{~mL}$ thorion-tapped glass tubes containing $20 \mathrm{~mL}$ of $4 \mathrm{~N} \mathrm{NaOH}$ were collected for helium isotope analysis. A pre-evacuated $50 \mathrm{~mL}$ gas tube was used to sample the gases for the determination of carbon isotopes in $\mathrm{CO}_{2}$. The La Sima dry vent was collected by inserting a titanium tube into the gas discharge, which was connected to a Tygon ${ }^{\mathrm{TM}}$ tube by means of a Dewar glass and then to the sampling vial. The gas sample was collected as previously described.

The inorganic residual gas compounds were analyzed by TCD- 
equipped gas-chromatographs (Shimadzu 15a and Thermo Focus). Methane and light hydrocarbons were analyzed with a Shimadzu 14a gas-chromatograph equipped with a FID. Carbon monoxide was determined with the same apparatus described for hydrocarbon analysis after its conversion to $\mathrm{CH}_{4}$ at $400^{\circ} \mathrm{C}$ by using a Shimadzu MTN-1 methanizer. Analytical precision was $<1 \%$ for major gas components and $<5 \%$ for minor and trace compounds.

The ${ }^{13} \mathrm{C} /{ }^{12} \mathrm{C}$ ratios in $\mathrm{CO}_{2}$ were determined by mass spectrometry by using a Finnigan Delta $S$ after a two-step extraction and purification procedure as previously described for the determination of $\delta^{13} \mathrm{C}_{\text {TDIC }}$ values. The analytical error was $\pm 0.05 \%$. The $\delta^{13} \mathrm{C}$ values of dissolved $\mathrm{CO}_{2}$ were calculated from the measured carbon isotopic ratios $\left(\delta^{13} \mathrm{C}\right.$ $\left.\mathrm{CO}_{2 \text { strip }}\right)$ in the dissolved gases on the basis of the enrichment factor $\left(\varepsilon_{1}\right)$ for gas-water isotope equilibrium proposed by Zhang et al. (1995), as follows:

$\varepsilon_{1}=\delta^{13} \mathrm{C}-\mathrm{CO}_{2}-\delta^{13} \mathrm{C}^{-\mathrm{CO}_{2 \text { strip }}}=(0.0049 \times \mathrm{T})-1.31$

Finally, the elemental abundance of helium (He), neon (Ne), and argon (Ar), and the isotopic analyses of helium (reported as R/Ra where $\mathrm{R}$ is the measured helium $\left({ }^{3} \mathrm{He} /{ }^{4} \mathrm{He}\right)$ isotopic ratio and $\mathrm{R}_{\mathrm{A}}$ is that of the air: $1.384 \times 10^{-6}$ and corrected using ${ }^{4} \mathrm{He} /{ }^{20} \mathrm{Ne}$ ratio), neon, and argon were performed using a Thermo Fisher Helix SFT mass spectrometer at The Ohio State University Noble Gas Laboratory (OSU NGL), following standard procedures summarized previously (Darrah et al., 2012, 2015; Eymold et al., 2018). The average external precision for noble gas concentrations based on "known-unknown" standards was within $\pm 1.64 \%$, with values reported in parentheses: ${ }^{4} \mathrm{He}$ concentrations $(0.67 \%),{ }^{22} \mathrm{Ne}$ concentrations $(1.23 \%)$, and ${ }^{36} \mathrm{Ar}$ concentrations $(0.31 \%)$. Noble gas isotopic standard errors were approximately \pm 0.0091 times the ratio of air $\left(1.384 \times 10^{-6}\right)$ for the ${ }^{3} \mathrm{He} /{ }^{4} \mathrm{He}$ ratio, less than $\pm 0.371 \%$ and $\pm 0.478 \%$ for ${ }^{20} \mathrm{Ne} /{ }^{22} \mathrm{Ne}$ and ${ }^{21} \mathrm{Ne} /{ }^{22} \mathrm{Ne}$ ratios, respectively, and less than $\pm 0.224 \%$ and $\pm 0.189 \%$ for ${ }^{38} \mathrm{Ar} /{ }^{36} \mathrm{Ar}$ and ${ }^{40} \mathrm{Ar} /{ }^{36} \mathrm{Ar}$ ratios, respectively. These values were determined by measuring referenced and cross-validated laboratory standards including an established atmospheric air standard (Lake Erie, Ohio Air), the Yellowstone MM standard, and a series of synthetic natural gas standards obtained from Praxair including known and cross-validated concentrations of $\mathrm{C}_{1}$ to $\mathrm{C}_{5}$ hydrocarbons, $\mathrm{N}_{2}, \mathrm{CO}_{2}, \mathrm{O}_{2}$, and each of the noble gases (Harkness et al., 2017; Moore et al., 2018).

\section{Results}

5.1. Chemical and isotopic $\left(\delta^{18} \mathrm{O}-\mathrm{H}_{2} \mathrm{O}, \delta \mathrm{D}-\mathrm{H}_{2} \mathrm{O}, \delta^{13} \mathrm{C}\right.$-TDIC, $\delta^{34} \mathrm{~S}_{-} \mathrm{SO}_{4}$, and ${ }^{87} \mathrm{Sr} /{ }^{86} \mathrm{Sr}$ ) composition of waters

Chemical compositions of the sampled waters are reported in Table 1, where water temperature (from 8.7 to $26^{\circ} \mathrm{C}$ ), $\mathrm{pH}$ (from 5.37 to 8.70 ), and electric conductivity (from 0.16 to $8.8 \mathrm{mS} / \mathrm{cm}$ ) are also reported. The electroneutrality parameter, calculated according Appelo and Postma (1993), was always $<5 \%$ (Table 1 ).

An initial assessment of the chemical composition of the CCVF thermal and cold waters is obtained by considering the $\mathrm{Cl}^{-}-\mathrm{SO}_{4}{ }^{2-}$ $\mathrm{HCO}_{3}{ }^{-}$(Fig. 3a) and $\left(\mathrm{Na}^{+}+\mathrm{K}^{+}\right.$)- $-\mathrm{Ca}^{2+}-\mathrm{Mg}^{2+}$ (Fig. 3b) ternary diagrams (expressed as \% meq/L). Most waters show a $\mathrm{HCO}_{3}-\mathrm{Mg}$ and $\mathrm{HCO}_{3}-\mathrm{Na}$ composition and rare $\mathrm{SO}_{4}(\mathrm{Cl})-\mathrm{Ca}(\mathrm{Mg})$ facies. Setting aside \#FAG5, \#H8, \#CRE12, and \#CRE15, the CCVF waters have a $\mathrm{SO}_{4}{ }^{2-} / \mathrm{Cl}^{-}$ratio of $\leq 1$ (Fig. 3a), while that of $\left(\mathrm{Na}^{+}+\mathrm{K}^{+}\right) / \mathrm{Mg}^{2+}$ is $<8$ with the exception of \#FD10 (45) (Fig. 3b). In the $\mathrm{HCO}_{3}{ }^{-}$vs. $\mathrm{SO}_{4}{ }^{2-}+\mathrm{Cl}^{-}$diagram (Fig. 4), in which iso-TIS (Total Ionic Salinity) lines are drawn, most waters are between 3 and $50 \mathrm{meq} / \mathrm{L}$, whereas \#H6, \#CRE12, \#H1, and \#H7 have a higher TIS (71, 85, 95, and $184 \mathrm{meq} / \mathrm{L}$, respectively). In detail, 3 groups of waters with different compositions can be recognized, as follows:

i) $\mathrm{HCO}_{3}-\mathrm{Mg}(\mathrm{Ca})$ : this group includes 11 water samples (\#BE1, \#H3b,
\#BDS4, \#CH7, \#H5, \#FO8, \#JA1, \#VC6, \#FAP2, \#H2, and \#FLT9), characterized by TIS ranging from 2.86 (\#FLT9) to 44.57 (\#CH7) meq/L, pH values from 5.6 (\#FAP2) to 6.5 (\#CH7), and temperatures from 13 (\#BDS4) to $22^{\circ} \mathrm{C}$ (\#H3b);

ii) $\mathrm{HCO}_{3}$-Na: 10 water samples (\#H4, \#FO1, \#VP1, \#H6, \#BLC1, \#BLC2, \#BLC3, \#H7, and \#H1) are referred to this group. They have with relatively high TIS, being comprised between 21.88 (\#VP1) and 184.04 (\#H7) meq/L, slightly acidic pH (5.9-6.2), and temperatures from 17 (\#FO1) to $26^{\circ} \mathrm{C}$ (\#H7);

iii) $\mathrm{SO}_{4}-\mathrm{Cl}-\mathrm{Ca}(\mathrm{Mg})$ : this group consists of 6 water samples with both low $\left(\# F D 10\right.$, TIS $=2.94 \mathrm{meq} / \mathrm{L}, \mathrm{pH}=5.4, \mathrm{t}=17^{\circ} \mathrm{C}$ ) and intermediate salinity (\#UBA1, \#FAG5, \#H8, \#CRE12, and \#CRE15, TIS $=21.48 \div 84.58 \mathrm{meq} / \mathrm{L}$ ), moderately neutral to basic $\mathrm{pH}$ values (up to 8.7 ), and temperatures ranging from 8.7 to $22^{\circ} \mathrm{C}$.

Fluoride and $\mathrm{Br}^{-}$contents were generally $<0.1 \mathrm{mg} / \mathrm{L}$, whereas $\mathrm{NH}_{4}{ }^{+}$and $\mathrm{NO}_{3}{ }^{-}$had a large variability, ranging from $<0.1$ to 10.6 (\#CRE12) $\mathrm{mg} / \mathrm{L}$ and from $<0.1$ to 101 (\#FAG5) mg/L, respectively.

Among the measured trace elements (Table 2), the highest concentrations were measured for Fe (up to $13,100 \mu \mathrm{g} / \mathrm{L}$ : \#FO1), Sr (up to $9765 \mu \mathrm{g} / \mathrm{L}$ : \#CRE12), Li (up to $1676 \mu \mathrm{g} / \mathrm{L}$ : \#FO1), B (up to $1009 \mu \mathrm{g} / \mathrm{L}$ : \#H1), and Mn (up to $784 \mu \mathrm{g} / \mathrm{L}$ : \#BE1) (Fig. 1S a, Supplementary Material) whereas, setting aside $\mathrm{Ba}, \mathrm{Al}$, and $\mathrm{Rb}$ (up to 224,157 , and $98 \mu \mathrm{g}$ / $\mathrm{L}$ measured for \#BCL1, \#FD10, and \#H1, respectively), all the other elements were $<50 \mu \mathrm{g} / \mathrm{L}$ (Fig. $1 \mathrm{~S}$ b, Supplementary Material) and often characterized by contents below the instrumental detection limit.

The isotopic composition of oxygen $\left(\delta^{18} \mathrm{O}\right)$, hydrogen $(\delta \mathrm{D})$, and strontium $\left({ }^{87} \mathrm{Sr} /{ }^{86} \mathrm{Sr}\right)$ in water, carbon in the TDIC $\left(\delta^{13} \mathrm{C}-\mathrm{TDIC}\right)$, and sulfur in $\mathrm{SO}_{4}\left(\delta^{34} \mathrm{~S}-\mathrm{SO}_{4}\right)$ are reported in Table 1 . The $\delta^{18} \mathrm{O}, \delta \mathrm{D}$, and $\delta^{13} \mathrm{C}$-TDIC values measured in 19 samples (\#VP1, \#FAP2, \#BDS4, \#FAG5, \#VC6, \#CH7, \#FO8, \#H1, \#UBA1, \#FO1, \#JA1, \#BE1, \#FD10, \#FLT9, \#CRE12, \#CRE15, \#BLC1, \#BLC2, and \#BLC3), ranged from -8.58 to $-0.68 \%$ and from -57.7 to $-18.9 \%$ os . VSMOW, and from -6.80 to $+2.21 \%$ vs. VPDB, respectively. The ${ }^{87} \mathrm{Sr} /{ }^{86} \mathrm{Sr}$ isotopic ratios measured in six samples (\#H1, \#H2, \#JA1, \#FLT9, \#CRE15, and \#BLC1) ranged between 0.70415 (\#JA1) and 0.71623 (\#FTL9). The $\delta^{34} \mathrm{~S}_{-} \mathrm{SO}_{4}$ values, analyzed in seven samples (\#H1, \#JA1, \#FLT9, \#CRE12, \#CRE15, \#BLC1, and \#BLC3), were between 10.7 (\#JA1) and 18.3 (\#BLC1) \%o vs. V-CDT.

\subsection{Chemical and isotopic $\left(\delta^{13} \mathrm{C}_{-}-\mathrm{CO}_{2}\right)$ composition of dissolved gases}

Dissolved gases were determined in springs (\#H2), rivers (\#H8), bubbling pools (\#H3b), and upwelling groundwater (\#BLC1 and \#BLC3). The chemical composition (in $\mathrm{mmol} / \mathrm{L}$ ) and the carbon isotopes in $\mathrm{CO}_{2}$ of the dissolved gases for the CCVF waters are listed in Table 3. $\mathrm{CO}_{2}$ was by far the most abundant gas species (up to $18.5 \mathrm{mmol} / \mathrm{L}$ ), followed by $\mathrm{N}_{2}$ (up to $0.57 \mathrm{mmol} / \mathrm{L}$ ). Methane, $\mathrm{O}_{2}$, and He were up to $0.0039,0.16$, and $0.00023 \mathrm{mmol} / \mathrm{L}$, respectively, while $\mathrm{H}_{2}$ was mostly $<0.00001 \mathrm{mmol} / \mathrm{L}$. The $\delta^{13} \mathrm{C}_{\mathrm{CO} 2}$ values in the dissolved gases were measured in the \#H2 $(-4.1 \%$ vs. VPDB) and \#H3B ( $-3.7 \%$ vs. VPDB) samples (Table 3 ).

\subsection{Chemical and isotopic $\left(\delta^{13} C_{\mathrm{CO} 2}, R / R_{A}\right.$ and $\left.{ }^{40} \mathrm{Ar} /{ }^{36} \mathrm{Ar}\right)$ compositions of free gases}

The chemical $\left(\mathrm{CO}_{2}, \mathrm{H}_{2} \mathrm{~S}, \mathrm{~N}_{2}, \mathrm{CH}_{4}, \mathrm{Ar}, \mathrm{O}_{2}, \mathrm{H}_{2}, \mathrm{Ne}\right.$, and $\left.\mathrm{He}\right)$ and isotopic (carbon in $\mathrm{CO}_{2}, \mathrm{He}$, and $\mathrm{Ar}$ ) compositions of the free-gas samples from CCVF (\#H1, \#H3, \#H4, \#H5, \#H6, \#H7, \#VP1, \#FAP2, \#LS3, \#BDS4, \#JA1, and \#FO8) are reported in Table 4. Carbon dioxide (up to $992 \mathrm{mmol} / \mathrm{mol}$ ) largely dominated the free-gas discharges, followed by $\mathrm{N}_{2}$ (from 0.71 to $13.5 \mathrm{mmol} / \mathrm{mol}$ ), $\mathrm{H}_{2} \mathrm{~S}$ (up to $0.8 \mathrm{mmol}$ / $\mathrm{mol}$ ), Ar (from $1 \times 10^{-2}$ to $3.1 \times 10^{-1} \mathrm{mmol} / \mathrm{mol}$ ), and $\mathrm{CH}_{4}$ (from $5 \times 10^{-4}$ to $\left.8 \times 10^{-2} \mathrm{mmol} / \mathrm{mol}\right)$. Minor concentrations were measured for $\mathrm{He}, \mathrm{H}_{2}$, and $\mathrm{Ne}$ : up $2.5 \times 10^{-2}, 1.4 \times 10^{-3}$, and $1.5 \times 10^{-4} \mathrm{mmol} / \mathrm{mol}$, respectively. No CO was detected. 


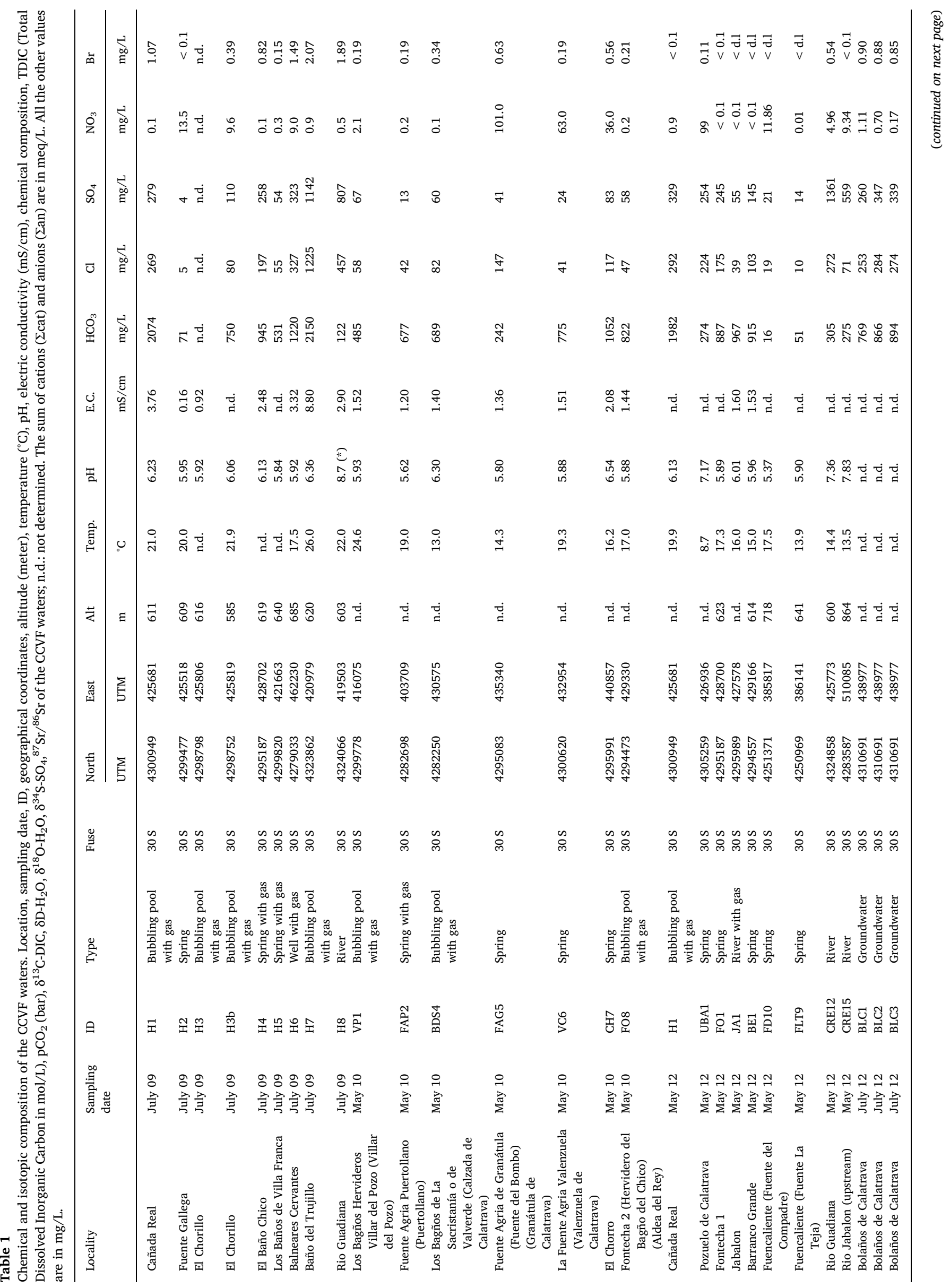




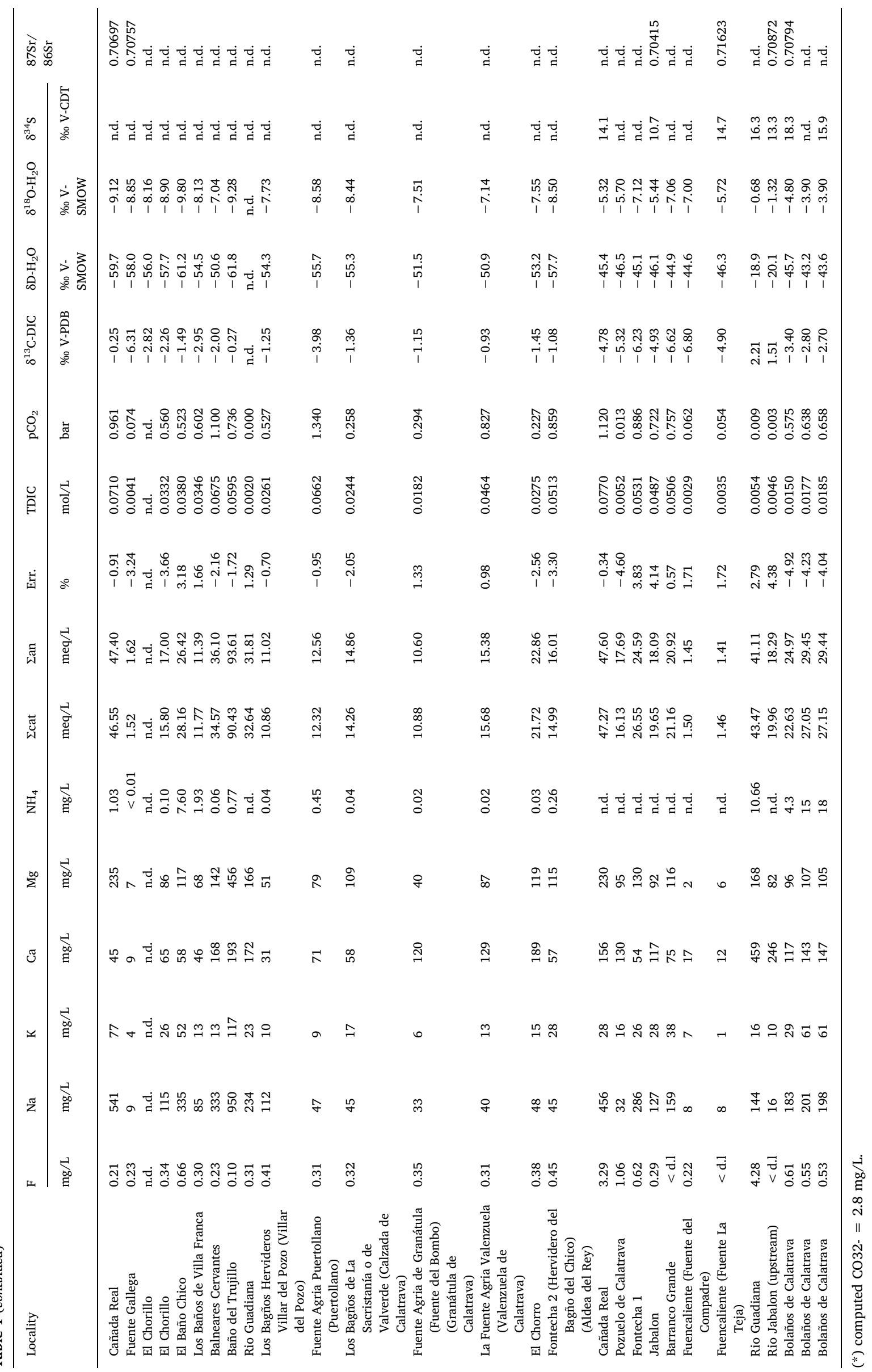



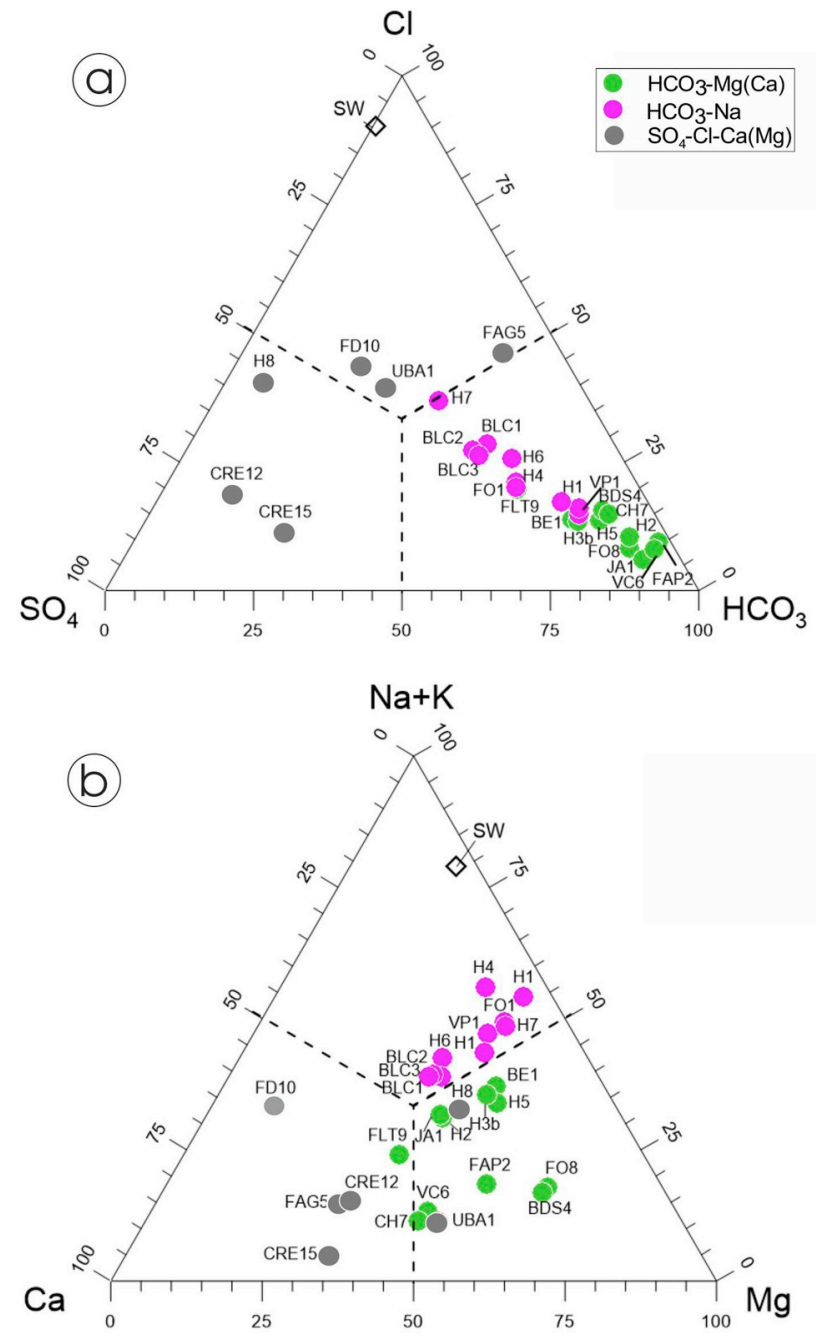

Fig. 3. Geochemical classification of the CCVF waters by (a) $\mathrm{SO}_{4}-\mathrm{Cl}-\mathrm{HCO}_{3}$ and (b) $\mathrm{Ca}-(\mathrm{Na}+\mathrm{K})-\mathrm{Mg}$ triangular diagrams.

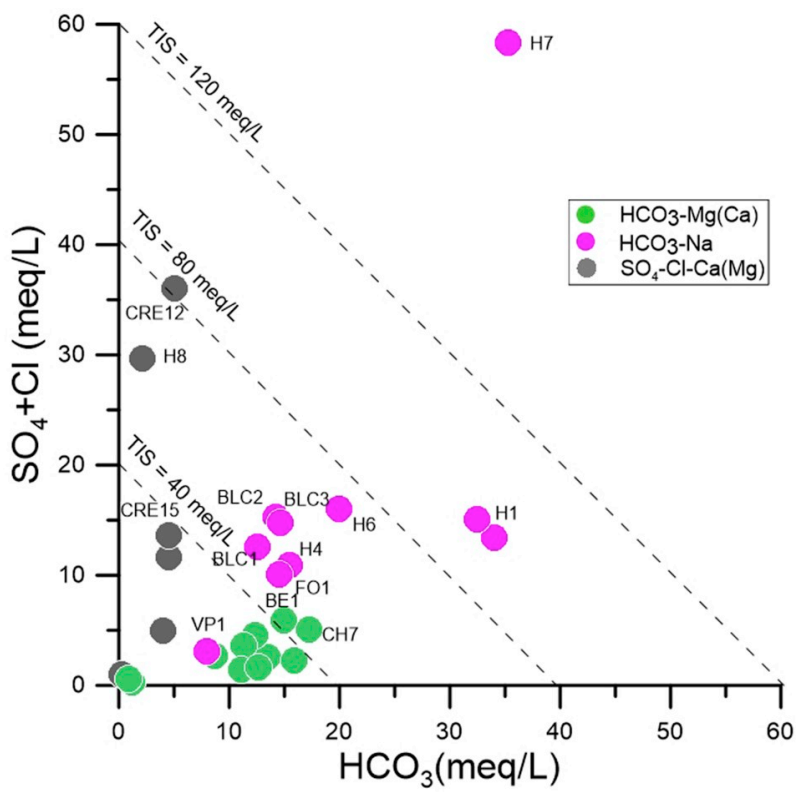

Fig. 4. $\left(\mathrm{SO}_{4}+\mathrm{Cl}\right)$ vs. $\mathrm{HCO}_{3}$ (in meq/L) binary diagrams of the CCVF waters. The dashed lines represent iso-Total Ionic Salinity (TIS) values.
Among volatile organic compounds (VOCs), the most abundant species were related to light alkanes $\left(\mathrm{C}_{2} \mathrm{H}_{6}\right.$ and $\mathrm{C}_{3} \mathrm{H}_{8}$ : up to $3 \times 10^{-3}$ and $1 \times 10^{-4} \mathrm{mmol} / \mathrm{mol}$, respectively), while $\mathrm{C}_{6} \mathrm{H}_{6}$ was found at very low concentrations (up to $8.4 \times 10^{-5} \mathrm{mmol} / \mathrm{mol}$ ); i- $\mathrm{C}_{4} \mathrm{H}_{8}$ and $\mathrm{i}-\mathrm{C}_{4} \mathrm{H}_{10}$ were detected in six samples $(\# \mathrm{H} 1, \# \mathrm{H} 3, \# \mathrm{H} 4, \# \mathrm{H} 5, \# \mathrm{H} 6, \# \mathrm{H} 7)$ at concentrations up to $9 \times 10^{-6}$ and $8 \times 10^{-6} \mathrm{mmol} / \mathrm{mol}$, respectively.

The $\delta^{13} \mathrm{C}$ values in $\mathrm{CO}_{2}$ in the free gas samples ranged from -6.8 (\#FAP2) to -3.2 (\#LS3) \%o VPDB. The helium isotopic ratios (measured in \#H4, \#H5, \#H6, \#VP1, and \#FO8), corrected for the presence of air in the mixture by using the $\mathrm{He} / \mathrm{Ne}$ ratio, varied from 1.06 (\#H6) to 2.73 (\#VP1) R/ $\mathrm{R}_{\mathrm{A}}$. Peréz et al. (1996) (in two unspecified sites from CCVF) measured 1.81 and $1.82 \mathrm{R} / \mathrm{R}_{\mathrm{A}}$, respectively, i.e. in the range of those determined in the present study, though lower. The Ar isotopic ratios $\left({ }^{40} \mathrm{Ar} /{ }^{36} \mathrm{Ar}\right.$; measured in the gas samples where the helium isotopes were analyzed) exceeded that of the air (295.5) since they were ranging from 300 to 407 .

\section{Discussion}

\subsection{Processes governing the chemical and isotopic composition of waters}

The $\delta^{18} \mathrm{O}-\mathrm{H}_{2} \mathrm{O}$ and $\delta \mathrm{D}-\mathrm{H}_{2} \mathrm{O}$ values of most waters are distributed along the Global Meteoric Water Line (GMWL; Craig, 1961) (from - 9.8 to $-7.0 \%$ and from -61.8 to $-44.5 \%$ for $\delta^{18} \mathrm{O}-\mathrm{H}_{2} \mathrm{O}$ and $\delta \mathrm{D}-\mathrm{H}_{2} \mathrm{O}$, respectively), pointing to a meteoric origin (Fig. 5). The relatively large isotopic variations can be explained in terms of different altitudes of the recharge areas. The CCVF thermal and cold waters are fed by rainfall between 600 and $700 \mathrm{~m}$ above sea level in according to the relationship between $\delta^{18} \mathrm{O}$ vs. altitude of about $-0.3 \%$ o $/ 100 \mathrm{~m}$, (e.g. Cruz-San et al., 1992). A few samples divert from the GMWL, possibly reflecting either prolonged water-rock interactions (though not supported by the relatively low salinity) or evaporation processes, and may play an important role due to the peculiarity of the fluid discharges since the waters often discharge inside small pools with scarce water exchange (Fig. 2). This is supported by the fact that i) the evaporation line reported in Fig. 5 intercepts the GMWL at the isotopic values of \#FAP2, \#FO8, and \#BDS4; and ii) the upwelling groundwater samples (\#BLC1, \#BLC2, \#BLC3; up to $-3.9 \%$ and $-43.2 \%$ for $\delta^{18} \mathrm{O}-\mathrm{H}_{2} \mathrm{O}$ and $\delta \mathrm{D}-\mathrm{H}_{2} \mathrm{O}$, respectively) are distributed along the same evaporation line. A second evaporation line consists of the river waters (\#CRE15, \#CRE12 up to $-0.7 \%$ and $-18.2 \%$ for $\delta^{18} \mathrm{O}-\mathrm{H}_{2} \mathrm{O}$ and $\delta \mathrm{D}-\mathrm{H}_{2} \mathrm{O}$, respectively). According to Gonfiantini (1986), the slope ("s" in Fig. 5) of these two evaporation lines is of 3.9 and 5, respectively, which corresponds to an area with relatively low humidity ( $\mathrm{h} \leq 0.5$ ), as expected in this part of Spain where temperatures during the day can reach $\geq 30^{\circ} \mathrm{C}$ with low humidity.

As previously stated, three groups of waters $\left(\mathrm{HCO}_{3}-\mathrm{Mg}(\mathrm{Ca}), \mathrm{HCO}_{3^{-}}\right.$ $\mathrm{Na}$, and rare $\mathrm{SO}_{4}-\mathrm{Cl}-\mathrm{Ca}(\mathrm{Mg})$ ) were recognized. The CCVF waters can mainly be regarded as the result of meteoric waters that, while infiltrating underground, react with (i) volcanic products characterized by Mg-rich volcanic alkaline rocks; (ii) silicate rocks (mainly represented by Paleozoic quartzites and sandstones); (iii) a deep-sourced $\mathrm{CO}_{2}$-rich gas phase; and (iv) waters from the Jabalón and Gaudiana rivers, which are rich in solutes derived by interactions with the Triassic evaporitic rocks (e.g. the Buntsandstein-Muschelkalk-Keuper Formations in Fig. 1).

The dissolution of $\mathrm{CO}_{2}$ causes a decrease in the $\mathrm{pH}$ (down to 5.3), enhancing the dissolution of $\mathrm{Mg}(\mathrm{Ca})$-rich carbonate minerals that, consequently, increase the abundances of $\mathrm{Ca}, \mathrm{Mg}$, and $\mathrm{HCO}_{3}$ in the water. Accordingly, most samples from the study area are approaching the stoichiometric $(\mathrm{Ca}+\mathrm{Mg}) / \mathrm{HCO}_{3}$ ratio (Fig. 2S, Supplementary Material). The $\mathrm{Ca}^{*} 3-\mathrm{HCO}_{3}-\mathrm{Mg} * 10$ triangular plot is reported in Fig. 3S (Supplementary Material), where the water composition expected for the $\mathrm{CO}_{2}$-driven dissolution of the dominant mineral phases that characterize the CCVF lithologies (Fig. 1) by stoichiometric reactions (e.g. calcite, dolomite, diopside, anorthite, and fosterite; eqs. (2)-(6)) are 
Table 2

-Trace element concentrations (in $\mu \mathrm{g} / \mathrm{L}$ ) in selected waters from CCVF.

\begin{tabular}{|c|c|c|c|c|c|c|c|c|c|c|c|c|c|c|c|c|}
\hline \multirow[t]{2}{*}{ ID } & $\mathrm{Al}$ & As & $\mathrm{Ba}$ & B & Cs & Co & $\mathrm{Cu}$ & $\mathrm{Fe}$ & $\mathrm{Hg}$ & $\mathrm{Li}$ & Mn & $\mathrm{Ni}$ & $\mathrm{Rb}$ & Se & $\mathrm{Sr}$ & $\mathrm{Zn}$ \\
\hline & $\mu \mathrm{g} / \mathrm{L}$ & $\mu \mathrm{g} / \mathrm{L}$ & $\mu \mathrm{g} / \mathrm{L}$ & $\mu \mathrm{g} / \mathrm{L}$ & $\mu \mathrm{g} / \mathrm{L}$ & $\mu \mathrm{g} / \mathrm{L}$ & $\mu \mathrm{g} / \mathrm{L}$ & $\mu \mathrm{g} / \mathrm{L}$ & $\mu \mathrm{g} / \mathrm{L}$ & $\mu \mathrm{g} / \mathrm{L}$ & $\mu \mathrm{g} / \mathrm{L}$ & $\mu \mathrm{g} / \mathrm{L}$ & $\mu \mathrm{g} / \mathrm{L}$ & $\mu \mathrm{g} / \mathrm{L}$ & $\mu \mathrm{g} / \mathrm{L}$ & $\mu \mathrm{g} / \mathrm{L}$ \\
\hline $\mathrm{H} 1 *$ & 4.7 & 0.5 & 22 & 1009 & 19 & 5.7 & 0.1 & 120 & 0.7 & 1203 & 311 & 14.9 & 98 & $<0.1$ & 94 & 26 \\
\hline $\mathrm{H} 2$ & 4.9 & 0.1 & 81 & 129 & $<1$ & 0.1 & 3.1 & 7 & 1.1 & 82 & 2 & 2.1 & 5.4 & $<0.1$ & 40 & 9.0 \\
\hline H3 & 34 & 0.1 & 39 & 423 & 5.0 & 1.1 & 2.7 & 8 & 11 & 594 & 127 & 6.7 & 40 & 0.1 & 109 & 18 \\
\hline FAP2 & 19 & 3.8 & 46 & 90 & 6.0 & 2.1 & 0.1 & 6683 & 0.7 & 160 & 509 & 5.0 & 19 & $<0.1$ & 22 & 9.3 \\
\hline BDS4 & 2.6 & 0.9 & 40 & 105 & 17 & 1.3 & 0.4 & 87 & 0.8 & 588 & 150 & 7.7 & 41.4 & $<0.1$ & 22 & 11 \\
\hline FAG5 & 33 & 0.1 & 93 & 45 & $<1$ & 0.6 & 5.9 & 8 & 0.8 & 64 & 31 & 6.4 & 9.2 & 0.9 & 391 & 23 \\
\hline VC6 & 23 & 0.5 & 199 & 105 & $<1$ & 0.3 & 21 & $<5$ & 1.0 & 61 & 6.8 & 3.4 & 5.4 & 0.2 & 1062 & 33 \\
\hline UBA1 & 1.9 & 0.5 & 131 & 76 & $<1$ & 0.2 & 0.4 & 6 & 10 & 52 & 2.2 & 0.7 & 1.1 & 0.3 & 3004 & 22 \\
\hline FO1 & 55 & 8.3 & 15 & 798 & 13 & 14 & 0.2 & 13100 & 0.3 & 1676 & 612 & 50.8 & 82 & $<0.1$ & 13 & 50 \\
\hline JA1 & 3.5 & 2.9 & 111 & 171 & $<1$ & 19 & 0.5 & 7600 & 0.4 & 279 & 544 & 2.3 & 63 & $<0.1$ & 455 & 13 \\
\hline BE1 & 20 & 2.3 & 27 & 417 & 13 & 16 & 0.1 & 4377 & 1.5 & 1236 & 784 & 38.7 & 61 & $<0.1$ & 18 & 28 \\
\hline FD10 & 157 & 4.7 & 26 & 34 & $<1$ & 3.8 & 19 & 23 & 2.4 & 5.0 & 75 & 2.8 & 4.1 & 0.2 & 24 & 32 \\
\hline FLT9 & 1.7 & 1.3 & 29 & 38 & $<1$ & 3.4 & 0.2 & 4361 & 0.7 & 28 & 481 & 7.9 & 2.8 & $<0.1$ & 19 & 12 \\
\hline CRE12 & 3.4 & 1.8 & 23 & 151 & $<1$ & 0.9 & 0.5 & 203 & 0.2 & 84 & 71 & 1.6 & 4.4 & 1.0 & 9765 & 2.6 \\
\hline CRE15 & 4.1 & 1.3 & 34 & 220 & $<1$ & 0.4 & 1.2 & 15 & 0.4 & 76 & 31 & 0.8 & 2.2 & 0.9 & 4063 & 4.0 \\
\hline BLC1 & 3.8 & 17 & 224 & 319 & $<1$ & 6.8 & 1.0 & 76 & 0.7 & 101 & 284 & 27.5 & 15 & 0.1 & 1481 & 4.7 \\
\hline BLC2 & 32 & 8.8 & 82 & 236 & 1.0 & 1.8 & 1.0 & 145 & 1.0 & 117 & 431 & 7.3 & 30 & 0.2 & 1559 & 5.4 \\
\hline BLC3 & 26 & 5.8 & 79 & 246 & 1.0 & 1.3 & 0.7 & 72 & 0.2 & 114 & 377 & 5.5 & 32 & 0.1 & 1585 & 7.0 \\
\hline
\end{tabular}

(*) July 09 .

reported as follows:

$$
\begin{aligned}
& \mathrm{CaCO}_{3}+\mathrm{CO}_{2}+\mathrm{H}_{2} \mathrm{O}=\mathrm{Ca}^{2+}+2 \mathrm{HCO}_{3}^{-} . \\
& \text {(calcite) }
\end{aligned}
$$

$\mathrm{CaMg}\left(\mathrm{CO}_{3}\right)_{2}+2 \mathrm{CO}_{2}+2 \mathrm{H}_{2} \mathrm{O}=\mathrm{Ca}^{2+}+\mathrm{Mg}^{2+}+4 \mathrm{HCO}_{3}^{-}$. (dolomite)

$\mathrm{CaMgSi}_{2} \mathrm{O}_{6}+4 \mathrm{CO}_{2}+2 \mathrm{H}_{2} \mathrm{O}=\mathrm{Ca}^{2+}+\mathrm{Mg}^{2+}+4 \mathrm{HCO}_{3}^{-}+2 \mathrm{SiO}_{2}$. (diopside)

$\mathrm{CaAl}_{2} \mathrm{Si}_{2} \mathrm{O}_{8}+2 \mathrm{CO}_{2}+3 \mathrm{H}_{2} \mathrm{O}=\mathrm{Al}_{2} \mathrm{Si}_{2} \mathrm{O}_{5}(\mathrm{OH})_{4}+\mathrm{Ca}^{2+}+2 \mathrm{HCO}_{3}^{-}$. (anorthite)

$\mathrm{Mg}_{2} \mathrm{SiO}_{4}+4 \mathrm{CO}_{2}+2 \mathrm{H}_{2} \mathrm{O}=2 \mathrm{Mg}^{2+}+4 \mathrm{HCO}_{3}^{-}+\mathrm{SiO}_{2}$.

$$
\text { (forsterite) }
$$

A $\mathrm{Ca}(\mathrm{Mg})-\mathrm{HCO}_{3}$ composition is attained in the initial stages of water-rock interaction processes due to calcite dissolution even in small amounts. This is related to the dissolution rate of calcite, being 2 to 6 orders of magnitude higher than that of silicate minerals, depending on the $\mathrm{pH}$ (Stumm and Morgan, 1996 and references therein). Setting aside samples \#CRE15, \#CRE12, \#H8, \#UBA1, \#FD10, and \#FAG5 (Fig. 3S, Supplementary Material), most waters have a $\mathrm{HCO}_{3}-\mathrm{Mg}(\mathrm{Ca})$ and $\mathrm{HCO}_{3}$ $\mathrm{Na}$ composition likely due to water-rock interactions with a $\mathrm{CO}_{2}$-rich gas phase and silicate minerals (eqs. (1)-(6)).

The chemical characteristics of the $\mathrm{HCO}_{3}-\mathrm{Mg}(\mathrm{Ca})$ waters (TIS $=3 \div$ $44 \mathrm{meq} / \mathrm{L}$ ) are typical of the first stages of interaction between meteoric and rocks, where the dominant concentration of $\mathrm{Mg}$ is attained by the alkaline rocks. The peculiar $\mathrm{HCO}_{3}-\mathrm{Na}$ composition, characterized by a clear enrichment in $\mathrm{Na}$ with respect to the stoichiometric $\mathrm{Na} / \mathrm{Cl}$ ratios (Fig. 6), is likely due to incongruent dissolution processes affecting Nasilicates during relatively long-lasting water-rock interaction as indicated by the TIS values (TIS $=22 \div 184 \mathrm{meq} / \mathrm{L}$ ), favored by the presence of a $\mathrm{CO}_{2}$-rich gas phase. The $\mathrm{SO}_{4}-\mathrm{Cl}-\mathrm{Ca}(\mathrm{Mg}$ ) waters (\#CRE15, \#CRE12 \#H8, \#FD10, \#FAG5, and \#UBA1) are likely influenced by an evaporitic component represented by the Triassic Formation drained by Guadiana and Jabalón rivers before entering the study area (Fig. 1). This implies that the waters discharging in the CCVF may be mixed with a $\mathrm{SO}_{4}$-Ca-rich shallow aquifer related to the two rivers. This is particularly evident when samples \#UBA1, \#FD10, and \#FAG5 springs are considered since the sulfur isotopic composition $(+10.7$ to $+18.3 \%$ vs. CDT; Table 1) intimately resembles that of gypsum/anhydrite from the Triassic evaporitic rocks (12.5-16.6\% vs. CDT; Ortí et al., 2014) in the Beltic Cordillera of the Germanic-type facies (Buntsandstein, Muschelkalk, and Keuper) (López-Gómez et al., 1993). Evaporitic rocks undergo water-rock interactions more rapidly than silicate rocks, hence their solutes have a major influence on water chemistry even if they are sporadically outcropping (Meybeck, 1987). The $\mathrm{Ca} / \mathrm{Na}, \mathrm{Mg} / \mathrm{Na}$, and $\mathrm{SO}_{4} / \mathrm{Na}$ molar ratios are particularly suited to distinguish waters interacting within the CCVF rocks, as shown in Fig. 7a and b. The three groups of waters are related to mixing processes with the $\mathrm{SO}_{4}(\mathrm{Ca}, \mathrm{Mg})$ evaporitic component that interacts with the shallow waters, the latter being due to the interaction with the alkaline volcanic rocks, whereas those with a $\mathrm{HCO}_{3}-\mathrm{Na}$ composition seem to be affected only to a very minor extent. Consequently, the relatively low $\mathrm{Mg} / \mathrm{Ca}$ and $\mathrm{Ca} / \mathrm{Na}$ ratios (mean value: 0.44 and 0.22 , respectively) recorded by $\mathrm{HCO}_{3}-\mathrm{Na}$ waters

\begin{tabular}{|c|c|c|c|c|c|c|c|c|c|c|c|}
\hline \multirow[t]{2}{*}{ ID } & \multirow[t]{2}{*}{ Sampling date } & $\mathrm{CO}_{2}$ & $\mathrm{~N}_{2}$ & $\mathrm{Ar}$ & $\mathrm{CH}_{4}$ & $\mathrm{O}_{2}$ & $\mathrm{Ne}$ & $\mathrm{He}$ & $\mathrm{H}_{2}$ & $\delta^{13} \mathrm{C}-\mathrm{CO}_{2}$ & \multirow[t]{2}{*}{$\mathrm{N}_{2} / \mathrm{Ar}$} \\
\hline & & $\mathrm{mmol} / \mathrm{L}$ & $\mathrm{mmol} / \mathrm{L}$ & $\mathrm{mmol} / \mathrm{L}$ & $\mathrm{mmol} / \mathrm{L}$ & $\mathrm{mmol} / \mathrm{L}$ & $\mathrm{mmol} / \mathrm{L}$ & $\mathrm{mmol} / \mathrm{L}$ & $\mathrm{mmol} / \mathrm{L}$ & V-PBD & \\
\hline $\mathrm{H} 2$ & July 09 & 3.05 & 0.570 & 0.014 & 0.0002 & 0.1321 & 0.00001 & 0.00004 & $<0.00001$ & -4.1 & 41.1 \\
\hline H3B & July 09 & 18.48 & 0.074 & 0.002 & 0.0039 & 0.0233 & $<0.00001$ & 0.00023 & $<0.00001$ & -3.7 & 41.7 \\
\hline H8 & July 09 & 0.15 & 0.475 & 0.008 & 0.0003 & 0.0033 & $<0.00001$ & 0.00001 & $<0.00001$ & n.d. & 58.9 \\
\hline BLC1 & July 12 & 0.00 & 0.380 & 0.011 & $<0.0001$ & 0.1626 & 0.00001 & n.d. & $<0.00001$ & n.d. & 36.2 \\
\hline BLC3 & July 12 & 0.91 & 0.564 & 0.014 & 0.0029 & 0.0039 & 0.00001 & n.d. & $<0.00001$ & n.d. & 39.4 \\
\hline
\end{tabular}

Table 3

Chemical and isotopic composition for the CCVF dissolved gases. The gas concentrations are in $\mathrm{mmol} / \mathrm{L}$. 


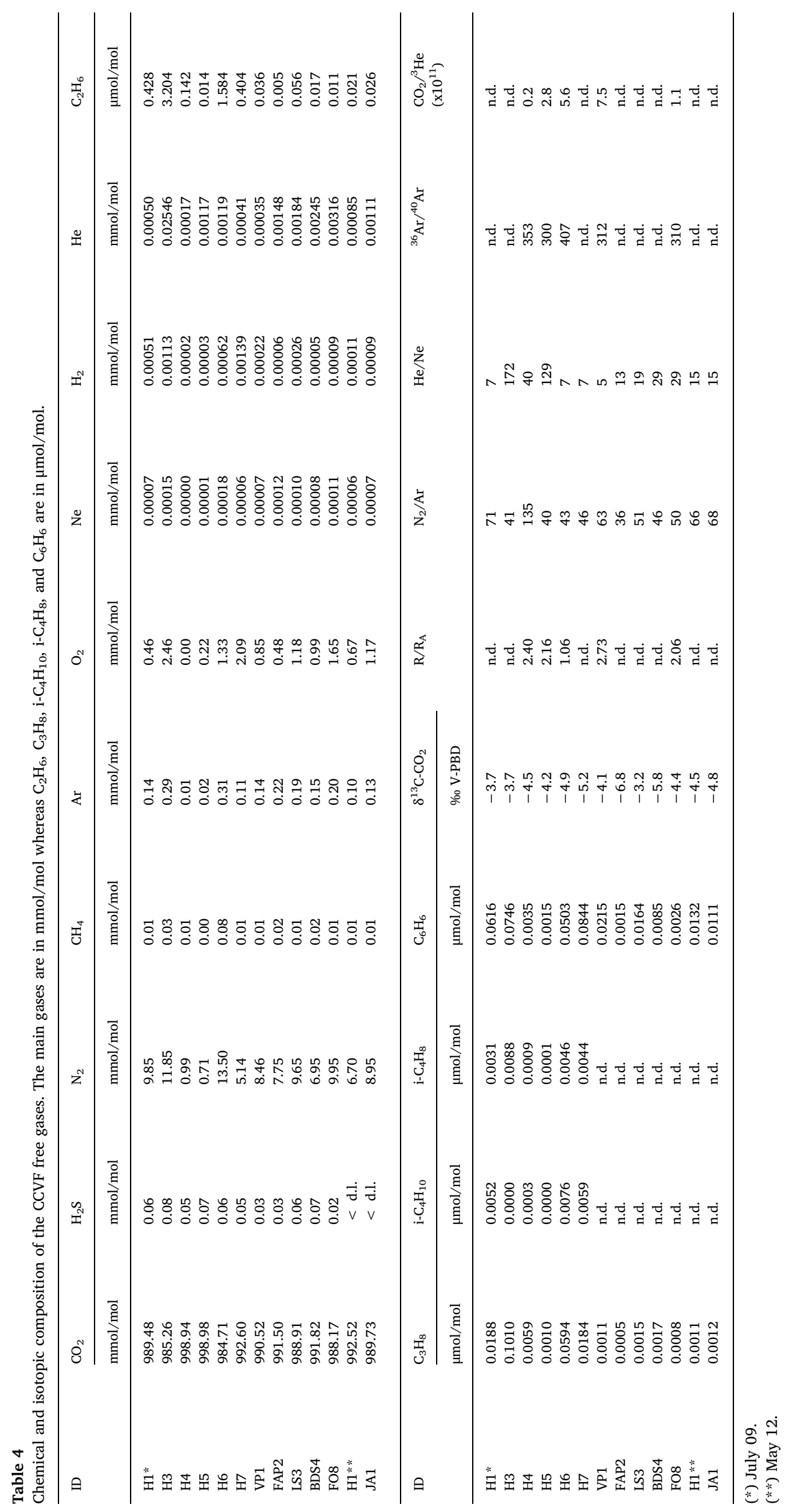




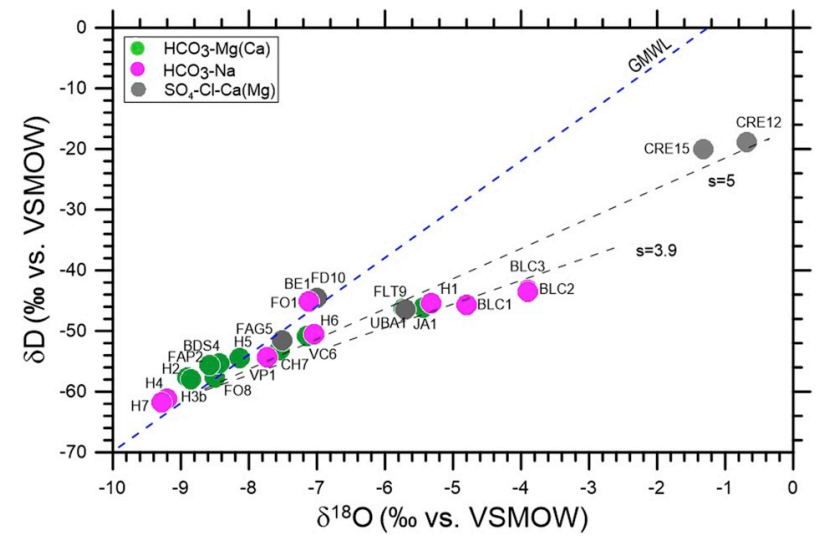

Fig. 5. $\delta \mathrm{D}$ vs. $\delta^{18} \mathrm{O}$ binary diagrams for the CCVF waters. Global Meteoric Water Line (GMWL) by Craig (1961); $\mathrm{s}$ is the slope at different relative humidities calculated according to Gonfiantini (1986).

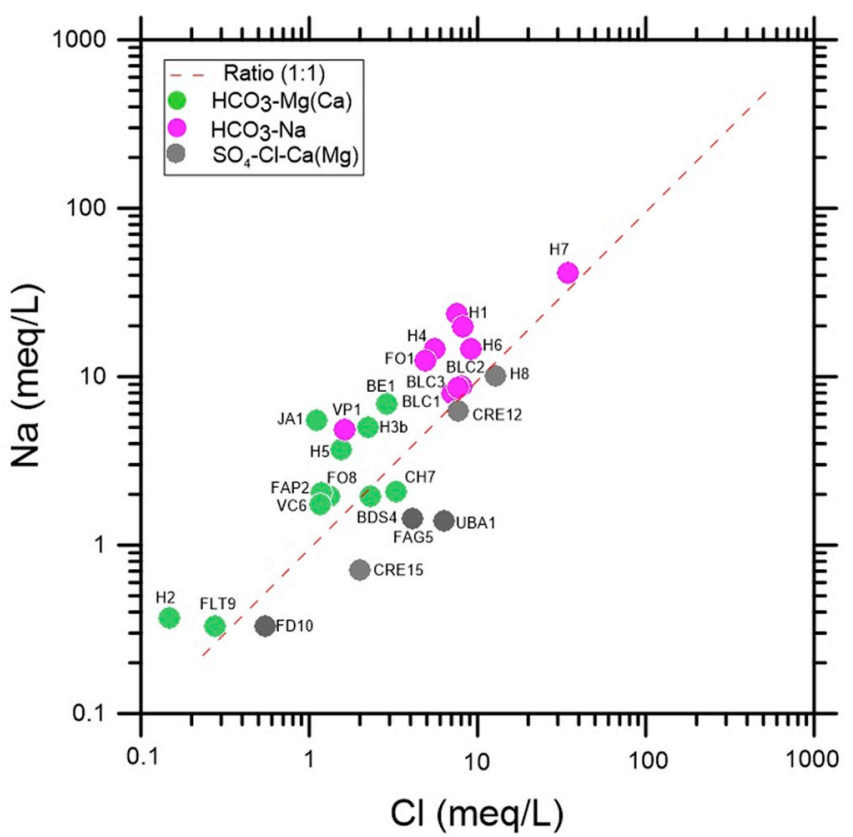

Fig. 6. (a) $\mathrm{Na}$ vs. $\mathrm{Cl}$ (in meq/L) and (b) $\mathrm{SO}_{4} \mathrm{vs}$. $\mathrm{Cl}$ (in meq/L) binary diagrams for the CCVF waters that include the stoichiometric (1:1) and seawater (1:1.2) and seawater (1:1.2) line, respectively. (associated with a $\mathrm{CO}_{2}$-rich gas phase), are likely referring to the dissolution of silicate minerals, which characterize the Paleozoic basement rocks. The $\mathrm{HCO}_{3}-\mathrm{Mg}(\mathrm{Ca})$ waters have higher $\mathrm{Mg} / \mathrm{Ca}$ and $\mathrm{Ca} / \mathrm{Na}$ ratios (mean value: 1.38 and 0.85 , respectively) than those classified as $\mathrm{HCO}_{3}-$ $\mathrm{Na}$ (Fig. $7 \mathrm{a}$ and b). The $\mathrm{SO}_{4}-\mathrm{Cl}-\mathrm{Ca}\left(\mathrm{Mg}\right.$ ) waters have higher $\mathrm{SO}_{4} / \mathrm{Na}$ $(=2.36)$ and $\mathrm{Ca} / \mathrm{Na}(=2.77)$ molar ratios, suggesting a strong contribution of $\mathrm{SO}_{4}, \mathrm{Ca}$, and $\mathrm{Na}$ by an evaporitic component.

The relatively high concentrations of $\mathrm{Sr}$ (up to $9765 \mu \mathrm{g} / \mathrm{L}$ ) observed in samples \#VC6, \#BA1, \#CRE12, \#CRE15, \#BLC1, \#BLC2, and \#BLC3 (Table 2) corroborate the occurrence of water-rock interaction processes, involving carbonate and sulfate minerals, since $\mathrm{Sr}$ is the main substitute for divalent ions, such as $\mathrm{Ca}$, and is easily released during dissolution. The $\mathrm{Sr}$ isotopic composition is a useful parameter that can be used to constrain water-rock interaction processes (e.g. Blum et al., 1994; Négrel et al., 2001; Nisi et al., 2008). The ${ }^{87} \mathrm{Sr} /{ }^{86} \mathrm{Sr}$ ratio is associated with the age of the geologic formations. If $\mathrm{Rb}$ is not present in the mineral phase, the ${ }^{87} \mathrm{Sr} /{ }^{86} \mathrm{Sr}$ ratio records the isotopic ratio of the medium from which a certain mineral was precipitated (e.g. calcite and gypsum/anhydrite). Since natural processes do not fractionate $\mathrm{Sr}$ isotopes, the measured differences in the ${ }^{87} \mathrm{Sr} /{ }^{86} \mathrm{Sr}$ ratios are likely due to either the isotopic signature inherited by the rocks with which the waters are interacting or mixing processes among rocks of different ages. The ${ }^{87} \mathrm{Sr} /{ }^{86} \mathrm{Sr}$ vs. $\mathrm{HCO}_{3} / \mathrm{HCO}_{3}+\mathrm{SO}_{4}$ ratios of Fig. 8 reports the selected waters (\#FLT9, \#CRE15, \#BLC1, \#H1, \#H2, and \#JA1) where the ${ }^{87} \mathrm{Sr} /{ }^{86} \mathrm{Sr}$ ratios were measured and those of the main CCVF rock end-members occurring in the study area, i.e., Triassic evaporites (Ortì at al., 2014), basaltic rocks (Ancochea and Moro, 1981), and Paleozoic rocks from the Betic belt (Benito et al., 1999). The ${ }^{87} \mathrm{Sr} /{ }^{86} \mathrm{Sr}$ isotopic ratios of the CCVF waters are varying between the relatively high radiogenic values of the Paleozoic basement (\#FLT9, $\left.{ }^{87} \mathrm{Sr} /{ }^{86} \mathrm{Sr}=0.71623\right)$ and those of the volcanic rocks, which are characterized by the low Sr isotopic ratio (e.g., Cebria et al., 1995) and are similar to that recorded in sample \#JA1 (0.70415). Setting aside the river water of \#CRE15 $\left[\mathrm{HCO}_{3}{ }^{-} /\left(\mathrm{HCO}_{3}{ }^{-}+\mathrm{SO}_{4}{ }^{2}\right)=0.23\right]$, the relatively low variability of the $\mathrm{HCO}_{3}{ }^{-} /\left(\mathrm{HCO}_{3}{ }^{-}+\mathrm{SO}_{4}{ }^{2-}\right)$ ratios (from 0.70 to 0.93 ) corresponds to a high variability in terms of ${ }^{87} \mathrm{Sr} /{ }^{86} \mathrm{Sr}$ ratios (from 0.70415 to 0.71623 ). The highest $\mathrm{HCO}_{3}{ }^{-}$/ $\left(\mathrm{HCO}_{3}{ }^{-}+\mathrm{SO}_{4}{ }^{2-}\right)$ ratios are found in \#JA1, \#H1, and \# H2 and related to the dissolution of a $\mathrm{CO}_{2}$-rich gas phase (Table 3). A similar process may have affected the samples \#FLT9 and \#BLC1, although a contribution by Paleozoic and Triassic evaporitic rocks, respectively, is expected. The lowest $\mathrm{HCO}_{3}{ }^{-} /\left(\mathrm{HCO}_{3}{ }^{-}+\mathrm{SO}_{4}{ }^{2-}\right)$ ratio was found in \#CRE15 (0.23), which is characterized by a dominant $\mathrm{SO}_{4}$-Ca facies $\left(\mathrm{Ca} / \mathrm{SO}_{4}\right.$ molar ratios $\left.\approx 1\right)$ and has inherited the $\mathrm{Sr}$ isotopic value by the dissolution of the gypsum/anhydrite from the Triassic evaporitic layers. As previously mentioned, large areas of the river basin (\#CRE15; $\delta^{34} \mathrm{~S}$ $\mathrm{SO}_{4}=+13.3 \%$ vs. CTD) are interacting with this lithology (Fig. 1).
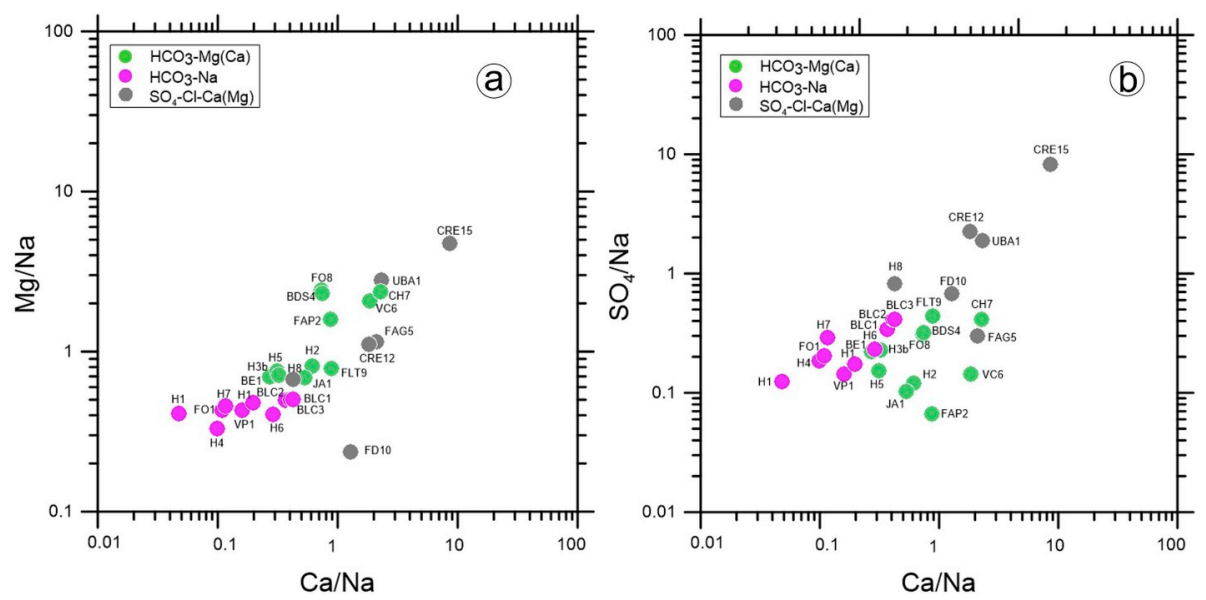

Fig. 7. Binary diagrams of (a) $\mathrm{Mg} / \mathrm{Na}$ vs. $\mathrm{Ca} / \mathrm{Na}$ and (b) $\mathrm{SO}_{4} / \mathrm{Na}$ vs. $\mathrm{Ca} / \mathrm{Na}$ molar ratios for the $\mathrm{CCVF}$ waters. 


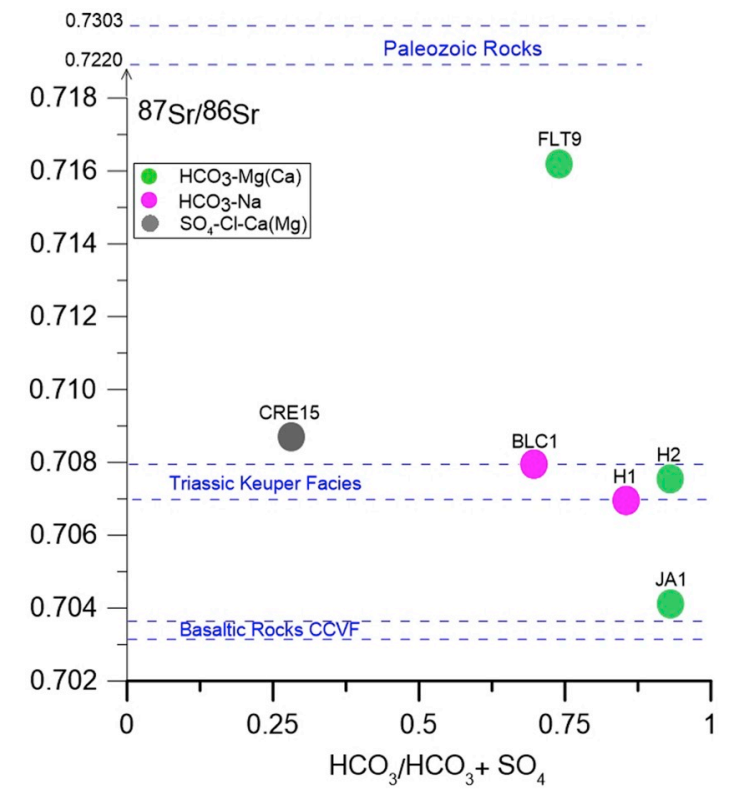

Fig. 8. Binary diagram of ${ }^{87} \mathrm{Sr} /{ }^{86} \mathrm{Sr}$ isotopic ratio vs. $\mathrm{HCO}_{3} /\left(\mathrm{HCO}_{3}+\mathrm{SO}_{4}\right)$ ratio. The strontium isotopic interval for the CCVF basalts (Ancochea and Moro, 1981), the Triassic Keuper facies (Ortì at al., 2014), and the Paleozoic rocks (Benito et al., 1999) are reported for comparison.

Field evidence, like bubbling waters and sporadic gas blowouts, suggests that the composition of these waters is related to the influx of a deep $\mathrm{CO}_{2}$-rich gas that is transported to shallow aquifers, i.e., the aquifer hosted in the basaltic volcanic rocks, though partly affected by those of the Guadiana and Jabalón rivers.

The relatively high concentrations of Co (\#JA1, \#FO1, and \#BE1), Fe (\#FO1, \#BE1, \#FD10, \#FLT9, \#FAP2, and \#JA1) and Mn (\#FO1, \#BE1, \#FAP2, and \#JA1) are likely related to their relatively low $\mathrm{pH}$ (from 5.37 to 6.06), i.e. the lowest $\mathrm{pH}$ values measured in the CCVF waters. These features are likely related to the hydrothermal activity, which was either subsequent to or associated with the magmatic activity, as suggested by the presence of deposits of Mn-Fe oxide with relatively high Co contents (Higueras and Millá, 2011). The relatively high concentrations of $\mathrm{Li}$ (\#H1, \#FO1, and \#BE1) and B (\#H1, \#FO1) further support the contribution by dissolution of evaporitic rocks.

\subsection{Comparison between theoretical and observed compositions: Total Dissolved Inorganic Carbon (TDIC) and $\delta^{13} C$-TDIC isotopic ratios}

The range of variation of the $\mathrm{P}_{\mathrm{CO} 2}$ in waters is related to the content of dissolved carbonic acid $\left(\mathrm{H}_{2} \mathrm{CO}_{3}\right)$ that is the main acidic substance driving mineral dissolution reactions. The higher the dissolved $\mathrm{CO}_{2}$, the lower the initial groundwater $\mathrm{pH}$. The low $\mathrm{pH}$ is then buffered by mineral weathering in soils and outcropping bedrocks. Calcite dissolution is the most common and effective buffering reaction. The alteration of silicate minerals also consumes $[\mathrm{H}]^{+}$, although these reactions proceed more slowly. Carbonate dissolution is sensitive to the partial pressure of $\mathrm{CO}_{2}$, i.e. the higher the dissolved $\mathrm{CO}_{2}$ the greater the solubility of calcite. This produces a relatively high TDIC content. Weathering of silicate minerals has a different effect on the carbonate system. The TDIC is solely derived from the $\mathrm{CO}_{2}$ consumed by alteration of feldspars, e.g. anorthite to form kaolinite (eq. (5)). As a consequence, in such reactions, the only change in the carbonate system is the associated increase in $\mathrm{pH}$, which shifts the distribution of TDIC species to $\mathrm{HCO}_{3}$ (the main species for $\mathrm{pH}$ values between $\mathrm{pH} 6.4$ and 10.3).

Mineral dissolution processes affecting most CCVF waters appear to be strictly controlled by $\mathrm{P}_{\mathrm{CO} 2}$. In the $\mathrm{P}_{\mathrm{CO} 2}$ vs. $\mathrm{pH}$ binary diagram of Fig. 4S (Supplementary Material), the studied waters are compared with the theoretical curves representing three iso-TDIC concentrations lines $\left(=10,100\right.$, and $1000 \mathrm{mgHCO}_{3} / \mathrm{L}$, respectively). The $\mathrm{HCO}_{3}-\mathrm{Mg}$ (Ca) and $\mathrm{HCO}_{3}$-Na waters show high TDIC and $\mathrm{P}_{\mathrm{CO} 2}$ values (TDIC > $1000 \mathrm{mg} \mathrm{HCO}_{3} / \mathrm{L}$ and up to $10^{+0.1}$ bar, respectively) whereas the $\mathrm{pH}$ ranges within a relatively narrow interval (from 5.5 to 6.5). The samples \#FD10, \#FLT9, \#H2, \#UBA1, \#CRE12, \#CRE15, and \#H8 are distributed along a decreasing trend since the TDIC values become lower as the $\mathrm{pH}$ increases $\left(\sim 100<\mathrm{TDIC}<500 \mathrm{mgHCO}_{3} / \mathrm{L}\right.$ and $10^{-3.6}<\mathrm{P}_{\mathrm{CO} 2}<10^{-1.2}$; respectively), the latter ranging between 5.4 and 8.7.

During weathering reactions, the carbon isotopic composition of TDIC $\left(\delta^{13} \mathrm{C}\right.$-TDIC) tends to evolve towards higher values (e.g. Clark and Fritz, 1997). For infiltrating meteoric waters, Frondini et al. (2009) and Nisi et al. (2013b) proposed an evolution model based on the addition of biogenic $\mathrm{CO}_{2}$, deeply derived $\mathrm{CO}_{2}$, and the simultaneous equilibrium dissolution of calcite. The TDIC contents vs. the $\delta^{13} \mathrm{C}$-TDIC values are reported in Fig. 5S (Supplementary Material), along with the theoretical curves simulating the TDIC and $\delta^{13} \mathrm{C}$-TDIC evolution. The theoretical curves were computed by means of the EQ3/6 code, starting from low (TDIC $=5.6 \times 10^{-4} \mathrm{~mol} / \mathrm{kg}$ ), to intermediate (TDIC $=4.1 \times 10^{-3} \mathrm{~mol} /$ $\mathrm{kg}$ ), to relatively high (TDIC $=2.0 \times 10^{-2} \mathrm{~mol} / \mathrm{kg}$ ) TDIC values. In order to investigate the effects of $\mathrm{CO}_{2}$ on the TDIC and $\delta^{13} \mathrm{C}$-TDIC values, the input of deep $\mathrm{CO}_{2}$ was modeled by the addition of $1.0 \times 10^{-2} \mathrm{~mol}$ of carbon to the infiltrating waters with a $\delta^{13} \mathrm{C}=-4.3 \%$ (V-PDB) (the mean value of the measured $\delta^{13} \mathrm{C}-\mathrm{CO}_{2}$ after excluding the most negative values, see Table 4) and calcite $\delta^{13} \mathrm{C}=0 \%$ (V-PDB), while the $\delta^{13} \mathrm{C}$ value of $\mathrm{CO}_{2}$ biogenic added to the solution was $\delta^{13} \mathrm{C}=-20 \%$ (V-PDB), which is comparable with oxidation processes of organic matter and/or root respiration (Nisi et al., 2016, and reference therein) (solid black curve in Fig. 5S, Supplementary Material). By comparison, the "deeply derived" $\mathrm{CO}_{2}$ is assumed to be originated from degassing mantle (Chiodini et al., 1999, 2000, 2004). The inspection of Fig. 5S (Supplementary Material) shows that the \#FAP2, \#H1, \#JA1, \#FO1, \#BE1, \#UBA1, \#H2, \#FD10, and \#FLT9 water samples are characterized by $2.9 \times 10^{-3}<$ TDIC $<7.710^{-2} \mathrm{~mol} / \mathrm{kg}$ and tend to be mainly distributed along the theoretical curves, representing the addition of deep $\mathrm{CO}_{2}$ (dash black curve in Fig. 5S, Supplementary Material), whose isotopic signature ( $\delta^{13} \mathrm{C}$-TDIC values from -6.80 to $-3.98 \%$ vs. V-PDB), suggests that the $\mathrm{CCVF}$ aquifer system is affected by $\mathrm{CO}_{2}$-rich gases from a deep source. A significant number of the CCVF waters are characterized by TDIC values ranging from $1.8 \times 10^{-2}$ and $6.7 \times 10^{-2} \mathrm{~mol} / \mathrm{kg}$ with those of $\delta^{13} \mathrm{C}$-TDIC varying from -2.8 to $-0.27 \%$ (V-PDB), i.e. related to the interaction with a deep-seated carbon. This hypothesis is supported by both the presence of large areas of $\mathrm{CO}_{2}$ degassing (Elio et al., 2015) and the $\mathrm{P}_{\mathrm{CO} 2}$ values estimated at reservoir conditions (pressure of 63 bars by González Cárdenas et al., 2015), which is, as expected, much higher than that computed at sampling conditions.

\subsection{Origin of gases}

The chemical composition of the free dissolved and gases from the CCVF is largely dominated by $\mathrm{CO}_{2}$, as it approaches concentrations up to $18.4 \mathrm{~mol} / \mathrm{L}$ and $999 \mathrm{mmol} / \mathrm{mol}$ respectively (Tables 3 and 4 ). In the free-gases, $\mathrm{N}_{2}$ (up to $9.95 \mathrm{mmol} / \mathrm{mol}$ ), and Ar (up to $0.31 \mathrm{mmol} / \mathrm{mol}$ ) are subordinate with respect to $\mathrm{CO}_{2}$. Much lower contents were recorded for $\mathrm{H}_{2} \mathrm{~S}$ (up to $0.08 \mathrm{mmol} / \mathrm{mol}$ ), $\mathrm{H}_{2}$ (up to $0.0011 \mathrm{mmol} / \mathrm{mol}$ ), $\mathrm{CH}_{4}$ (up to $\left.0.034 \mathrm{mmol} / \mathrm{mol}\right)$, He $(0.025 \mathrm{mmol} / \mathrm{mol})$, and $\mathrm{VOC}$ $\left(\Sigma_{\mathrm{VOC}}=3.38 \mu \mathrm{mol} / \mathrm{mol}\right)$.

According to the $\mathrm{N}_{2} / \mathrm{Ar}$ ratios (Tables 3 and 4), these inert gases are mainly related to an atmospheric component, their ratios ranging between that of air (83) and that of ASW (Air Saturated Water; $\mathrm{N}_{2}$ / $\mathrm{Ar}=38)$, with the exception of sample $\mathrm{H} 4\left(\mathrm{~N}_{2} / \mathrm{Ar}=135\right)$ for which a contribution from deep-seated $\mathrm{N}_{2}$ can be invoked, this sample showing the lowest concentration of $\mathrm{Ar}$ and $\mathrm{O}_{2}$ and the highest content of $\mathrm{CO}_{2}$. Based on the ${ }^{40} \mathrm{Ar} /{ }^{36} \mathrm{Ar}$ ratio (from 300 to 407) that often exceeds that of the air, the presence of a radiogenic component of $\mathrm{Ar}$ in the studied 


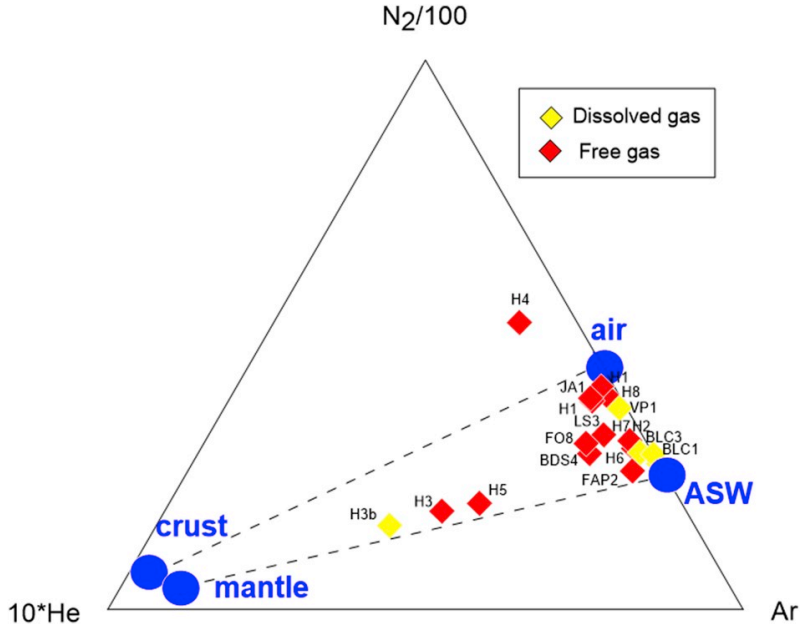

Fig. 9. $\mathrm{N}_{2} / 100$-Ar-10*He triangular diagram for the free (red diamond) and dissolved (yellow diamond) gases from CCVF. (For interpretation of the references to colour in this figure legend, the reader is referred to the Web version of this article.)

samples can be suggested. The predominantly atmospheric origin of $\mathrm{N}_{2}$ and $\mathrm{Ar}$ can also be visualized by using the $\mathrm{N}_{2}$ - $\mathrm{Ar}-\mathrm{He}$ triangular diagram (Giggenbach, 1996, Fig. 9). This diagram illustrates how the CCVF gases appear to be related to a mixing process between a mantle component (as suggested by the relatively high $\mathrm{R} / \mathrm{Ra}$ values, Table 4) and an atmospheric component (either air or ASW Air Saturated Water). According to the R/Ra values measured in the ultramafic xenoliths from the CCVF (ca. 6.5Ra) hosted in the alkaline rocks, Martelli et al. (2011) suggested that these values can be associated with metasomatic processes due to ascending HIMU-type astenospheric melts and they are in agreement with what observed in other xenoliths from the European mantle (e.g. Dunai and Bauer, 1995). The helium isotope (R/ $\mathrm{Ra})$ ratios in the CCVF are indeed lower $(<3 \mathrm{Ra}$, Table 4$)$ than those expected for upper mantle volatiles $(\approx 8 \mathrm{Ra})$ and consistent with a mantle component that experienced metasomatism either during the interaction with crustal fluids (Hilton et al., 2002) or, more likely, typical of rift-related continental area (Bell et al., 2013), possibly diluted by a crustal component, associated with the Paleozoic basement. It can thus be estimated that up to $40 \%$ of a metasomatized mantle component is present in the analyzed gases, this value being slightly higher than those calculated in two gas samples collected from the CCVF by Perez et al. (1996). The carbon isotopic values of $\mathrm{CO}_{2}$ are between -3.2 and $-6.8 \%$ V-PDB, i.e. in the range suggested for primary mantle carbon $(-6.5 \pm 2.5 \%$ V-PDB, e.g. Sano and Marty, 1995). However, the CCVF gas samples show a $\mathrm{CO}_{2} /{ }^{3} \mathrm{He}$ ratio $>10^{11}$, which significantly exceeds that typically measured for strictly mantle-derived gases $\left(2 \times 10^{9}-1 \times 10^{10}\right.$, e.g. Marty et al., 1989; Sano and Marty, 1995; Sano and Williams, 1996) and overlaps or is even higher than those measured in fumarolic discharges associated with subduction-related volcanic systems or typically observed from water washing (Tedesco et al., 2009; Darrah et al., 2013). Consequently, an unequivocal origin for $\mathrm{CO}_{2}$ cannot be invoked although the presence of a mantle signature, possibly modified by the input of a shallower (e.g. carbonate) component as suggested by the $\mathrm{CO}_{2} /{ }^{3} \mathrm{He}$ ratios, is likely. Nevertheless, secondary processes occurring before the emergence of the $\mathrm{CO}_{2}$-rich bearing thermal waters cannot be ruled out (Venturi et al., 2017). No isotopic data are available for sulfur isotopes in $\mathrm{H}_{2} \mathrm{~S}$ and carbon and hydrogen isotopes in methane, though present at very low concentrations, and their origin cannot be unequivocally distinguished. However, if the $\mathrm{CH}_{4} /\left(\mathrm{C}_{2} \mathrm{H}_{6}+\mathrm{C}_{3} \mathrm{H}_{8}\right)$ ratio (the so-called "Bernard parameter", after Bernard et al., 1978) is considered, all the gas samples are $<1,000$, with the exception of \#FAG2 (4500), and some of them are close or even $<100$. The intermediate values between a thermogenic ("Bernard parameter" < 100) and a microbial ("Bernard parameter" > 1000) source (Whiticar and Suess, 1990; Jenden et al., 1993) are likely produced by both microbial activity and thermal maturation of sedimentary organic matter. However, a thermogenic source can be invoked for samples \#H1 to \#H7 and \#LS3. In addition, the presence of $\mathrm{C}_{6} \mathrm{H}_{6}$ and $\mathrm{C}_{4+}$ hydrocarbons in the CCVF gases suggests a minor contribution from a thermogenic component (e.g. Tassi et al., 2012). A detailed isotopic investigation on methane and $\mathrm{H}_{2} \mathrm{~S}$ is necessary before formulating more specific hypotheses.

\subsection{Geothermometry}

González Cárdenas et al. (2015) reported that a hydrothermal system below CCVF is present with temperature of $118-120^{\circ} \mathrm{C}$. However, no information whether these values were obtained by using liquid and/or gas geothermometers or derived by exploratory geothermal wells were reported. The authors simply referred that the geothermometric data were produced during some projects lead by the Instituto Volcanológico de Canarias (INVOLCAN) and Grupo de Investigación: Geomorfología, Territorio y Paisaje en Regiones Volcánicas (GEOVOL). On the other hand, Benítez-Navío and Pulido-Bosch (2010) described the problems related to the application of liquid geothermometry and suggested a hypothetical equilibrium temperatures of about $70^{\circ} \mathrm{C}$. Consequently, in this section, we used our data in order verify whether geothermometric estimations can be applied to the CCVF waters and gases. It is to be pointed out that the outlet temperatures of the studied emergences were $<30^{\circ} \mathrm{C}$, although a slightly higher temperature was recorded at Baños de Fuencaliente $\left(38^{\circ} \mathrm{C}\right)$, was not sampled in present work.

The most commonly used empirical geothermometers are based on the theoretical assumption of equilibrium between water and the typical mineral authigenic assemblage of medium to high temperature $\left(150-300^{\circ} \mathrm{C}\right)$ hydrothermal systems (e.g. Giggenbach, 1988; Chiodini et al., 1991). As already discussed, the $\mathrm{HCO}_{3}$ - $\mathrm{Na}$ waters can be regarded as the deeper liquid component among the studied waters, likely released from and equilibrated within the Paleozoic basement and affected by a deeper gas (mostly consisting of $\mathrm{CO}_{2}$ ) root. The Na-K-Mg $\mathrm{Mg}^{1 / 2}$ triangular diagram of Giggenbach (1988) (Fig. 6S, Supplementary Material) shows that the $\mathrm{HCO}_{3}$-Na waters are positioned close to the $\mathrm{Mg}$ corner ("immature waters"), likely resulting by a mixing process with the shallower aquifer $\left(\mathrm{HCO}_{3}-\mathrm{Mg}\right)$ located inside the alkaline volcanic products. Consequently, it appears that the $\mathrm{HCO}_{3}$-Na deep waters are not the result of high temperature equilibrium. Moreover, the mixing process between upwelling deep waters and a shallow cold aquifer could contribute to the decrease in the concentrations of the deep-related solutes (e.g. $\mathrm{SiO}_{2}$ ) due to re-equilibration processes. Since no equilibrium is achieved along with the presence of abundant $\mathrm{CO}_{2}$, silica, and alkaline(earth) geothermometers (e.g. Fournier and Truesdell, 1973; Fouillac and Michard, 1981; Giggenbach, 1988), when applied to the CCVF waters, give very different and unrealistic deep reservoir temperatures compared to those reported by González Cárdenas et al. (2015). If the equilibrium temperature and physical data described in González Cárdenas et al. (2015) are correct, the CCVF hydrothermal system would occur at a depth of $640 \mathrm{~m}$ and a pressure of 63 bars. This would mean that the geothermal gradient at CCVF is comparable to that of Larderello (Italy; e.g. Ceccarelli et al., 1987; Minissale, 1991; Della Vedova et al., 2007). Therefore, unless other evidences to support the data of González Cárdenas et al. (2015) are provided, such temperature estimations are to be thought overestimated, since they are clearly affected by the presence of shallow aquifers.

Gas geothermometry is applied to gases with low solubility (e.g. $\mathrm{CH}_{4}, \mathrm{H}_{2}$, and $\mathrm{CO}_{2}$ ) since the relative ratios are not affected by significant compositional variations as they rise from the reservoir to the surface. Consequently, the $\mathrm{CH}_{4}-\mathrm{CO}_{2}-\mathrm{H}_{2}$ system (e.g. Giggenbach, 1987; Giggenbach, 1991) was applied to the CCVF gases. However, no realistic data were obtained, likely due to the presence of a shallow 


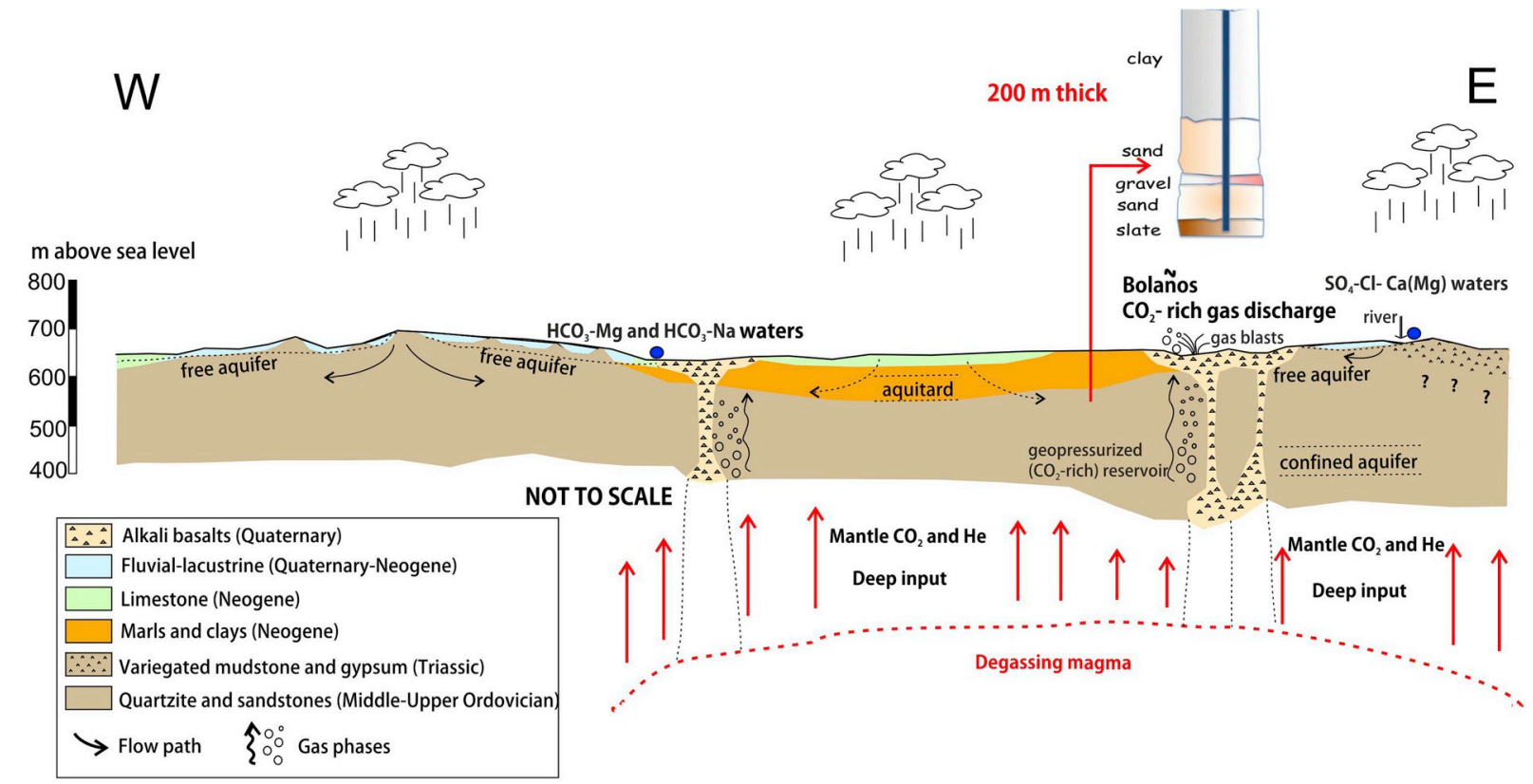

Fig. 10. Conceptual model of fluid circulation in the CCVF. The stratigraphic sequence reported on the left-hand side of the figure is reconstructed after the Bolaños gas blast occurred in 2011.

component that masks the chemical composition attained at depth. Similar results were computed by using the $\log \left(\mathrm{X}_{\mathrm{H} 2} / \mathrm{X}_{\mathrm{Ar}}{ }^{*}\right)$ vs. $\log \left(\mathrm{X}_{\mathrm{CO} 2} /\right.$ $\left.\mathrm{X}_{\mathrm{Ar}^{*}}\right)$ plot (Giggenbach, 1991), suggesting once again the non-applicability of any appropriate geothermometer to estimate the equilibrium temperature at depth for the CCVF deep reservoir.

\subsection{Conceptual model}

Groundwaters in CCVF flow at different depths according to the conceptual model proposed in Fig. 10. The meteoric waters infiltrate through the Paleozoic and younger rocks and fed the following aquifers: i) groundwater table characterized by relatively rapid circulation through high permeability formations (Upper Pliocene clastic alluvial sediment), locally affected by that of the Guadiana and Jabalón rivers; ii) groundwater system inside the alkaline volcanic products; iii) aquitard in accordance with the slow infiltration through the low permeability formations (Neogene marls and clays) and, iv) confined aquifer located inside the Ordovician basement (quarzites and sandstones). The Paleozoic basement can be interpreted as a fractured zone consistent with the main fault patterns of the region which also favors the upward migration of $\mathrm{CO}_{2}$ that gradually dissolves into the deep reservoir. Consequently, the salinity tends to increase (TIS up to 184 meq/L; \#H7) and waters acquire a $\mathrm{HCO}_{3}-\mathrm{Na}$ composition. When these waters rise through the fault systems and along the volcanic conduits, characterized by $\mathrm{Mg}$-rich alkaline rocks, they increase their $\mathrm{Mg}$ concentration from the alteration of the alkaline rocks. The shallower aquifers are fresh waters and, in the absence of deep gases, have a neutral $\mathrm{pH}$, relatively low salinity, and $\mathrm{HCO}_{3}-\mathrm{Mg}(\mathrm{Ca})$ composition. On the contrary, if these shallow waters interact with the deep-seated $\mathrm{CO}_{2}$ rich gases, the $\mathrm{pH}$ values decrease and their metal content increases. The Guadiana and Jabalón rivers, whose waters are $\mathrm{SO}_{4}(\mathrm{Cl})-\mathrm{Ca}(\mathrm{Mg})$ since they drain the Triassic evaporitic rocks before entering the CCVF, are possibly responsible of further mixing processes with the emerging deep waters.

\section{Conclusions}

The $\mathrm{CO}_{2}$-rich gas discharges at the Campo de Calatrava Volcanic Field (central-southern Spain), occurring as dry vents or, more commonly, bubbling into the numerous thermal waters $\left(<30^{\circ} \mathrm{C}\right)$ present in the area, are likely representing the ultimate remnants of the past volcanic activity. The helium isotope values measured in this study are up to $2.73 \mathrm{R} / \mathrm{Ra}$, i.e. higher than those measured by Perez et al. (1996), but lower than those recorded in the CCVF mantle xenoliths where values up to $6.74 \mathrm{Ra}$, similar to other European mantle xenoliths, were measured (Martelli et al., 2011) and related to a metasomatized mantle.

The tentative conceptual model of fluid circulation (Fig. 10) reconciles the complex geochemistry recorded by the low-thermality waters since mixing processes among compositionally different aquifers were evidenced. Nevertheless, the $\mathrm{HCO}_{3}-\mathrm{Na}$ waters are likely representing the deep component of the CCVF hydrothermal system, possibly located in the Paleozoic basement. However, it is reasonable to suppose that the root of the gases is related to the degassing magma at depth. Unfortunately, liquid and gas geothermometers did not produce any reliable data, likely due to both the interference between the deep component and the shallower aquifers and the effects of secondary processes, respectively.

It is however important to note that the relatively frequent gas blasts occurring during drilling of domestic wells indicate a $\mathrm{CO}_{2}$-rich pressurized system at relatively low depth. This study has not highlighted evidences on how to reduce the risks related to new possible violent gas eruptions during well drilling. Consequently, detailed geophysical and hydrogeological studies are to be carried out to evidence those areas more prone to gas accumulation at relatively shallow depths. In addition, an estimation of the $\mathrm{CO}_{2}$ output from CCVF affecting this part of continental Spain is required, considering that previous investigations carried out at La Sima and Rio Jabalón have reported relatively high $\mathrm{CO}_{2}$ fluxes since they were up to 5379 and $1 \times 10^{6} \mathrm{~g} \mathrm{~m}^{-2} \mathrm{~d}^{-1}$, respectively (Elío et al., 2015).

\section{Acknowledgments}

The Municipality of Almagro is gratefully acknowledged for the help provided during the sampling activities. We would like to thank Dr. Luis Perez del Villar for his help during the first sampling fieldwork at CCVF. We wish to thank D. Melero Cabañas who accompanied us in the field to collect the water samples during the first survey. Many 
thanks are also due to the personnel of Amphos21 (J. Bruno, A. Cedez, F. Grandia) and Ciudad de la Energia (D. Angel) and F. Capecchiacci (Dept. Earth Science of Florence) for their help during the second survey.

We would like to acknowledge the comments and suggestions provided by two reviewers, who greatly improved an early version of the manuscript.

This work was partially funded by Ciudad de la Energia (Resp. OV; Grant contract: ALM-08-006) and the Laboratory of Stable Isotopes and Fluid Geochemistry of the Department of Earth Sciences (University of Florence).

\section{Appendix A. Supplementary data}

Supplementary data to this article can be found online at https:// doi.org/10.1016/j.apgeochem.2019.01.011.

\section{References}

Ancochea, E., 1999. El Campo volcanico de Calatrava. Enseñanza de las Ciencias de la Tierra 7 (3), 237-243.

Ancochea, E., 2004. La región volcánica del Campo de Calatrava. In: Vera, J.A. (Ed.), Geología de España. Sge Igme, Madrid, pp. 676-677.

Ancochea, E., Bränle, J.L., 1982. Alineaciones de volcanes en la Región Volcánica Central Española. Rev. Geofisc. 38, 133-138.

Ancochea, E., Moro, A., 1981. ${ }^{87} \mathrm{Sr} /{ }^{86} \mathrm{Sr}$ ratios of Basaltic rocks from Campos de Calatrava (Central Spain). Estud. Geol. (Madr.) 37, 27-33.

Appelo, C.A.J., Postma, D., 1993. Geochemistry, Groundwater and Pollution. A. A. Balkema, Rotterdam, Brookfield, pp. 536.

Atekwana, E.A., Krishnamurthy, R.V., 1998. Seasonal variations of dissolved inorganic carbon and $813 \mathrm{C}$ of surface waters: application of a modified gas evolution technique. J. Hydrol 205, 265-278.

Avanzinelli, R., Boari, E., Conticelli, S., Francalanci, L., Guarnieri, L., Perini, G., Petrone, C.M., Tommasini, S., Ulivi, M., 2005. High precision Sr, Nd, and Pb isotopic analyses using the new generetion thermal ionisation mass spectrometer ThermoFinnigan Triton-Ti. Period. Mineral. 75 (3), 1-20.

Bailey, K., Garson, M., Kearns, S., Velasco, A.P., 2005. Carbonate volcanism in Calatrava, central Spain: a report on the initial findings. Mineralog. Mag. 69, 907-915.

Becerra-Ramírez, R., Escobar, E., González, E., Dóniz-Páez, J., Becerra-Ramírez, M.C., 2017. Recursos para el geoturismo en la región volcánica de Campo de Calatrava (Ciudad Real, España central). In: Carcavilla, L., Duque-Macías, J., Giménez, J., Hilario, A., Monge-Ganuzas, M., Rodríguez, J. Vegas y A. (Eds.), Patrimonio geológico, gestionando la parte abiótica del patrimonio natural. Cuadernos del Museo Geominero, $n^{\circ} 21$ Instituto Geológico y Minero de España, Madrid, pp. 309-314 (In Spanish with English abstract).

Becerra-Ramírez, R., González Cárdenas, E., Dóniz, J., Gosálvez Rey, R.U., Escobar, E. 2010. Análisis morfométrico de los volcanes de la cuenca media del río Jabalón. Región Volcánica del Campo de Calatrava (Ciudad Real, España). In: Escobar, E., Becerra, R., Gosálvez, R.U., Dóniz, J. (Eds.), Aportaciones recientes en volcanología 2005-2008, González, E. Centro de Estudios Calatravos, UCLM, Ministerio de Ciencia y Tecnología, pp. 111-115 978-84-614-1025-5.

Bell, K., Lavecchia, G., Rosatelli, G., 2013. Cenozoic Italian magmatism - isotope constraints for possible plume-related activity. J. S. Am. Earth Sci. 41, 22-40.

Benítez Navío, A., Pulido Bosch, A., 2010. Consideraciones hidrogeológicas sobre el Campo de Calatrava (Ciudad Real). In: González Cárdenas, E., Escobar Lahoz, E. Becerra Ramírez, R., Ubaldo Gosálvez Rey, R., Dóniz Páez, J. (Eds.), Aportaciones recientes en Vulcanología, pp. 83-89.

Benito, R., Lopez-Ruiz, J., Cebrià, J.M., Hertogen, J., Doblas, M., Oyarzun, R., Demaiffe, D., 1999. Sr and O isotope constraints on source and crustal contamination in the high-K calc-alkaline and shoshonitic neogene volcanic rocks of SE Spain. Lithos 46, $773-802$.

Bernard, B.B., Brooks, J.M., Sackett, W.M., 1978. A geochemical model for characterization of hydrocarbon gas sources in marine sediments. In: Offshore Technology Conference, Houston, USA, pp. 435-438.

Bianchini, G., Beccaluva, L., Bonadiman, C., Nowell, G.M., Paerson, D.G., Siena, F., Wilson, M., 2010. Mantle metasomatism by melts of HIMU piclogite component: new insights from Fe-lherzolite xenoliths (Calatrava Volcanic District, Central Spain). In: In: Coltorti, M., Downes, H., Gregoire, M., O'Reilly, S.Y. (Eds.), Petrological Evolution of the European Lithospheric Mantle 337. London Geological Society, Special Publications, pp. 107-124.

Blum, J.D., Erel, Y., Brown, K., 1994. ${ }^{87} \mathrm{Sr} /{ }^{86} \mathrm{Sr}$ ratios of Sierra Nevada stream waters: implications for relative mineral weathering rates. Geochem. Cosmochim. Acta 57 (21-22), 5019-5025.

Carracedo Sánchez, M., Sarrionandia, F., Arostegui, J., Larrondo, E., Gil Ibarguchi, J.I. 2009. Development of spheroidal composite bombs by welding of juvenile spinning and isotropic droplets inside a mafic eruption column. J. Volcanol. Geoth. Res. 186, 265-279.

Carracedo Sánchez, M., Sarrionandia, F., Arostegui, J., Eguiluz, L., Ibarguchi, J.I.G., 2012. The transition of spatter to lava-like body in lava fountain deposits: features and examples from the Cabezo Segura volcano (Calatrava, Spain). J. Volcanol. Geoth. Res.
227-228, 1-14.

Cebriá, J.M., López-Ruiz, J., 1995. Alkali basalts and leucitites in an extensional intracontinental plate setting: the Late Cenozoic Calatrava Volcanic Province (Central Spain). Lithos 35, 27-46.

Cebriá, J.M., López-Ruiz, J., Carmona, J., Doblas, M., 2009. Quantitative petrogenetic constraints on the Pliocene alkali basaltic volcanism of the SE Spain Volcanic Province. J. Volcanol. Geoth. Res. 185, 172-180.

Cebriá, J.M., López-Ruiz, J., Doblas, M., Oyarzun, R., Hertogen, J., Benito, R., 2000. Geochemistry of the Quaternary alkali basalts of Garrotxa (NE Volcanic Province, Spain): a case of double enrichment of the mantle lithosphere. J. Volcanol. Geoth. Res. 102, 217-235.

Ceccarelli, A., Celati, R., Grassi, S., Minissale, A., Ridolfi, A., 1987. The southern boundary of Larderello geothermal field. Geothermics 16, 505-515.

Chiodini, G., Cardellini, C., Amato, A., Boschi, E., Caliro, S., Frondini, F., Ventura, G., 2004. Carbon dioxide Earth degassing and seismogenesis in central and southern Italy. Geophys. Res. Lett. 31, L07615. https://doi.org/10.1029/2004GL019480.

Chiodini, G., Cioni, R., Guidi, M., Marini, L., 1991. Chemical geothermometry and geobarometry in hydrothermal solutions: a theoretical investigation based on a mineralsolution equilibrium model. Geochem. Cosmochim. Acta 55, 2709-2727.

Chiodini, G., Frondini, F., Cardellini, C., Parello, F., Peruzzi, L., 2000. Rate of diffuse carbon dioxide earth degassing estimated from carbon balance of regional aquifers: the case of central Apennine Italy. J. Geophys. Res. 105, 8423-8434.

Chiodini, G., Frondini, F., Kerrick, D.M., Rogie, J.D., Parello, F., Peruzzi, L., Zanzari, A.R., 1999. Quantification of deep $\mathrm{CO}_{2}$ fluxes from Central Italy. Examples of carbon balance for regional aquifers and of soil diffuse degassing. Chem. Geol. 159, 205-222.

Clark, I., Fritz, P., 1997. Environmental Isotopes in Hydrogeology. CRC Press, New York, pp. 328.

Craig, H., 1961. Isotopic variations in meteoric waters. Science 133, 1702-1703.

Crespo, A., 1992. Geologia, Mineralogia y Genesis de yacimientos de Manganeso Cobaltifero del Campo de Calatrava (Ciudad Real). PhD Thesis. UCM, pp. 389.

Cruz-San, J., Araguas, L., Rozanski, K., Benavente, J., Cardenal, J., Hidalgo, M.C., Garcia-Lopez, S., Martinez-Garrido, J.C., Moral, F., Olias, M., 1992. Sources of precipitation over South-Eastern Spain and groundwater recharge. An isotopic study. Tellus 44b, 226-236.

Cuoco, E., Tedesco, D., Poreda, R.J., Darrah, T.H., 2013. Impact of volcanic plume emissions on rain water chemistry during the January 2010 Nyamuragira eruptive event: implications for essential potable water resources. J. Hazard Mater. 244, $570-581$.

Darrah, T.H., Poreda, R.J., 2012. Evaluating the accretion of meteoritic debris and interplanetary dust particles in the GPC-3 sediment core using noble gas and mineralogical tracers. Geochem. Cosmochim. Acta 84, 329-352.

Darrah, T.H., Jackson, R.B., Vengosh, A., Warner, N.R., Whyte, C.J., Walsh, T.B., Kondash, A.J., Poreda, R.J., 2015. The evolution of Devonian hydrocarbon gases in shallow aquifers of the northern Appalachian Basin: insights from integrating noble gas and hydrocarbon geochemistry. Geochem. Cosmochim. Acta 170, 321-355.

Darrah, T.H., Tedesco, D., Tassi, F., Vaselli, O., Poreda, R.J., 2013. Gas chemistry of the dallol geothermal field of the danakil depression in the Afar region of the northern most east african rift. Chem. Geol. 339. https://doi.org/10.1016/j.chemgeo.2012.10. 036.

De Vicente, G., Vegas, R., Muñoz Martín, A., Silva, P.G., Andriessen, P., Cloetingh, S., González Casado, J.M., Van Wees, J.D., Álvarez, J., Carbó, A., Olaiz, A., 2007. Cenozoic thick-skinned deformation and topography evolution of the Spanish Central System. Glob. Planet. Chang. 58, 335-381.

Della Vedova, B., Vecellio, C., Bellani, S., Tinivella, U., 2007. Thermal modelling of the Larderello geothermal field (Tuscany, Italy). Int. J. Earth Sci. (Geol. Rundsch). https://doi.org/10.1007/s00531-007-0249-0.

Doblas, M., López-Ruiz, J., Cebriá, J.M., 2007. Cenozoic evolution of the Alboran Domain: a review of the tectonomagmatic models. In: Beccaluva, L., Bianchini, G., Wilson, M. (Eds.), Volcanism in the Mediterranean Area. Geol. Soc. Am, pp. 303-320.

Doveri, M., Mussi, M., 2014. Water isotopes as environmental tracers for conceptual understanding of groundwater flow: an application for fractured aquifer systems in the "Scansano-Magliano in Toscana" area (Southern Tuscany, Italy). Water (Switzerland) 6 (8), 2255-2277.

Duggen, S., Hoernle, K., Van Den Bogaard, P., Harris, C., 2004. Magmatic evolution of the Alboran region: the role of subduction in forming the western Mediterranean and causing the Messinian salinity crisis. Earth Planet. Sci. Lett. 218, 91-108.

Duggen, S., Hoernle, K., Van Den Bogaard, P., Garbe-Schonberg, D., 2005. Post-collisional transition from subduction- to intraplate- type magmatism in the westernmost Mediterranean: evidence for continental-edge delamination of subcontinental lithosphere. J. Petrol. 46, 1155-1201.

Dunai, T.J., Baur, H., 1995. Helium, neon, and argon systematics of the European subcontinental mantle: implications for its geochemical evolution. Geochem. Cosmochim. Acta 59, 2767-2783.

Elio, J., Ortega, M.F., Nisi, B., Mazadiego, L.F., Vaselli, O., Caballero, J., Grandia, F., 2015. $\mathrm{CO}_{2}$ and $\mathrm{Rn}$ degassing from the natural analogue of Campo de Calatrava (Spain): implications for monitoring of $\mathrm{CO}_{2}$ storage sites. Int. J. Greenhouse Gas Control 32, 1-14.

Escobar, E., González, E., 2010. Itinerario por los hervideros o cultura de los baños. Recurso didáctico para el estudio y conservación del paisaje volcánico del Campo de Calatrava (Ciudad Real, España). In: Geografía, Educación y Formación del profesorado en el marco del Espacio Europeo de Educación Superior, AGE, UCM, Murcia I. pp. 287-299.

Eymold, W.K., Swana, K., Moore, M.T., Whyte, C.J., Harkness, J.S., Talma, S., Murray, R., Moortgat, J.B., Miller, J., Vengosh, A., Darrah, T.H., 2018. Hydrocarbon-rich groundwater above shale gas formations: a Karoo Basin case-study. Gr. Water 56 (2). https://doi.org/10.1111/gwat12637. 
Fouillac, C., Michard, G., 1981. Sodium/lithium ratio in water applied to geothermometry of geothermal reservoirs. Geothermics 10 (Issue 1), 55-70.

Fournier, R.O., Truesdell, A.H., 1973. An empirical Na-K-Ca geothermometer for natural waters. Geochem. Cosmochim. Acta 37, 1255-1275.

Frondini, F., Caliro, S., Cardellini, C., Chiodin, i G., Morgantini, N., 2009. Carbon dioxide degassing and thermal energy release in the Monte Amiata volcanic-geothermal area (Italy). Appl. Geochem. 24, 860-875.

Gasparini, A., Sainz-García, A., Grandia, F., Bruno, J., 2016. Atmospheric dispersion modelling of a natural $\mathrm{CO}_{2}$ degassing pool from Campo de Calatrava (northeast Spain) natural analogue. Implications for carbon storage risk assessment. International Journal of Greenhouse Gas Control 47, 38-47.

Giggenbach, W.F., 1987. Redox processes governing the chemistry of fumarolic gas discharges from White Island, New Zealand. Appl. Geochem. 2, 143-161.

Giggenbach, W.F., 1988. Geothermal solute equilibria. Derivation of Na-K-Mg-Ca geoindicators. Geochem. Cosmochim. Acta 52, 2749-2765.

Giggenbach, W.F., 1991. Chemical Techniques in Geothermal Exploration. Application of Geochemistry in Geothermal Reservoir Development. UNITAR, New York, pp. 253-273 1991.

Giggenbach, W.F., 1996. Chemical composition of volcanic gases. In: Scarpa, R., Tilling, T.I. (Eds.), Monitoring and Mitigation of Volcanic Hazards. Springer, New York, pp. 221-256.

Gonfiantini, R., 1986. Environmental isotopes in lake studies. In: In: Fritz, P., Fontes, J.Ch (Eds.), Handbook of Environmental Isotope Geochemistry 2. The Terrestrial Environment, B, Elsevier, Amsterdam, pp. 113-168 1986.

Gonzáles Cárdenas, E., Gosálvez Rey, R.U., Becerra Ramírez, R., Escobar Lahoz, E., 2007. Actividad eruptiva holocena en el Campo de Calatrava (Volcán Columba, Ciudad Real, España). In: Lario, J., Silva, G. (Eds.), XII Reunión Nacional de Cuaternario, pp. 143-144 Ávila, España.

González Cárdenas, E., Calvo Fernández, D., Becerra Ramírez, R., Escobar Lahoz, E., Gosálvez Rey, R.U., Pérez Rodríguez, N., 2015. Expulsiones violentas de gases magmáticos en el Campo de Calatrava (Ciudad Real, España). In: de la Riva, J., Ibarra, P., Montorio, R., Rodrigues, M. (Eds.), 2015 Análisis Espacial Y Representación Geográfica: Innovación Y Aplicación: 1639-1648. Universidad de Zaragoza-AGE 978-84-92522-95-8.

González Cárdenas, E., Gosálvez Rey, R.U., 2004. Nuevas aportaciones al conocimiento del hidrovolcanismo en el Campo de Calatrava (España). In: VIII Reunión Nacional de Geomorfología, septiembre 2004, Toledo, España.

González Cárdenas, E., Gosálvez, R.U., Becerra, R., Escobar, E., 2010. El trabajo reciente de los geógrafos en el volcanismo del Campo de Calatrava. In: González, E., Escobar, E., Becerra, R., Gosálvez, R.U., Dóniz, J. (Eds.), Aportaciones recientes en volcanología 2005-2008. Centro de Estudios Calatravos, UCLM, Ministerio de Ciencia y Tecnología, pp. 91-95.

Gutiérrez Marco, J.C., Robardet, M., Rábano, I., Sarmiento, G.N., San José Lancha, M.A., Herranz Araújo, P., Pieren Pidal, A.P., 2002. Chapter 4, ordovician. In: Gibbons, W., Moreno, T. (Eds.), The Geology of Spain. The Geological Society, London, pp. 31-49.

Harkness, J.S., Darrah, T.H., Moore, M.T., Whyte, C.J., Mathewson, P.D., Cook, T., Vengosh, A., 2017. Naturally occurring versus anthropogenic sources of elevated molybdenum in groundwater: evidence for geogenic contamination from southeast Wisconsin, United States. Environ. Sci. Technol. 51 (21), 12190-12199.

Herrero-Hernández, A., López-Moro, F.J., Gallardo-Millán, J.L., Martín-Serrano, A., Gómez-Fernández, 2015. Volcanism-sedimentation interaction in the Campo de Calatrava Volcanic Field (Spain): a magnetostratigraphic and geochronological study. Int. J. Earth Sci. (Geol. Rundsch). https://doi.org/10.1007/s00531-014-1053-2.

Higueras, P., Millán, J., 2011. The Campo de Calatrava volcanic field: geology and resources. History of Research in Mineral Resources. Cuadernos Del Museo Geominero 13. pp. 395-404.

Hilton, D.R., Fisher, T.P., Marty, B., 2002. Noble gases and volatile recycling at subduction zones. Rev. Mineral. Geochem. 47, 319-370.

Humphreys, E.R., Bailey, K., Hawkesworth, C.J., Wall, F., Najorka, J., Rankin, A.H., 2010. Aragonite in olivine from Calatrava, Spain e evidence for mantle carbonatite melts from $>100 \mathrm{~km}$ depth. Geology 38, 911-914.

IGME, 1988. In: Mapa geologico de Espainia 1: 50000, Hoja 784, Ciudad Real 2 serie, 1 edition. pp. 101.

Jenden, P.D., Hilton, D.R., Kaplan, I.R., Craig, H., 1993. Abiogenic hydrocarbons and mantle helium in oil and gas fields. In: Howell, D.G. (Ed.), The Future of Energy Gases: US Geological Survey Professional Paper, 1570, pp. 31-56.

López-Gómez, J., Mas, R., Arche, A., 1993. The evolution of the Middle Triassic (Muschelkalk) carbonate ramp in the SE Iberian Ranges, eastern Spain: sequence stratigraphy, dolomitization processes and dynamic controls. Sediment. Geol. 87, 165-193.

López-Ruiz, J., Cebriá, J.M., Doblas, M., 2002. Cenozoic volcanism I: the iberian peninsula. In: Gibbons, W., Moreno, T. (Eds.), The Geology of Spain. Geological Society, London, pp. 417-438.

López-Ruiz, J., Cebriá, J.M., Doblas, M., Oyarzun, R., Hoyos, M., Martín, C., 1993. Cenozoic intra-plate volcanism related to extensional tectonics at Calatrava, central Iberia. Journal of the Geology Society 150, 915-922.

Lustrino, L., Wilson, M., 2007. The circum-Mediterranean anorogenic Cenozoic igneous province. Earth Sci. Rev. 81, 1-65.

Martelli, M., Bianchini, G., Beccaluva, L., Rizzo, A., 2011. Helium and argon isotopic compositions of mantle xenoliths from Tallante and Calatrava, Spain. J. Volcanol. Geoth. Res. 200, 18-26.

Marty, B., Jambon, A., Sano, Y., 1989. Helium isotopes and $\mathrm{CO}_{2}$ in volcanic gases of Japan. Chem. Geol. 76, 25-40.

Melero Cabañas, D., 2007. Ciudad Real: tierra de hervideros, fuentes y baños de aguas minero-medicinales. Imprenta Provincial, Ciudad Real, pp. 254.

Meybeck, M., 1987. Global chemical weathering of surficial rocks estimated from river dissolved loads. Am. J. Sci. 287, 401-428.

Minissale, A., 1991. The Larderello geothermal field: a review. Earth Sci. Rev. 31, 133-151.

Montegrossi, G., Tassi, F., Vaselli, O., Buccianti, A., Garofalo, K., 2001. Sulphur species in volcanic gases. Anal. Chem. 73 (3) 709-3,715.

Moore, M.T., Vinson, D.S., Whyte, C.J., Eymold, W.K., Walsh, T.B., Darrah, T.H., 2018. Differentiating between biogenic and thermogenic sources of natural gas and hydrocarbon geochemistry. In: Lawson, M., Formolo, M.J., Eiler, J.M. (Eds.), From Source to Seep: Geochemical Applications in Hydrocarbon Systems. 468 Geological Society, London, Special Publications. https://doi.org/10.1144/SP468.8.

Négrel, Ph, Casanova, J., Aranyossy, J.F., 2001. Strontium isotope systematics used to decipher the origin of grounwaters sampled from granitoids: the Vienne Case (France). Chem. Geol. 177, 287-308.

Nisi, B., Buccianti, A., Vaselli, O., Perini, G., Tassi, F., Minissale, A., Montegrossi, G., 2008. Hydrogeochemistry and strontium isotopes in the Arno River Basin (Tuscany, Italy): constraints on natural controls by statistical modelling. J. Hydrol 360, 166-183.

Nisi, B., Raco, B., Dotsika, E., 2016. Groundwater contamination studies by environmental isotopes: a review. In: In: Scozzari, A., Dotsika, E. (Eds.), Threats to the Quality of Groundwater Resources: Prevention and Control, Hdb Env. Chem. 40. Springer-Verlag Berlin Heidelberg, pp. 115-150. https://doi.org/10.1007/698_2014_ 281. Published online: , Accessed date: 3 October 2014.

Nisi, B., Vaselli, O., Delgado Huertas, A., Tassi, F., 2013a. Dissolved nitrates in the groundwater of the cecina plain (tuscany, central-western Italy): clues from the isotopic signature of $\mathrm{NO}_{3}{ }^{-}$. Appl. Geochem. 34, 38-52.

Nisi, B., Vaselli, O., Tassi, F., Elío, J., Delgado Huertas, A., Mazadiego, L.F., Ortega, M., 2013b. Hydrogeochemistry of surface and underground waters in the HontominHuermeces area (Burgos, Spain). Int. J. Greenhouse Gas Control. 14, 151-168.

Ortí, F., Pérez-López, A., García-Veigas, J., Rosell, L., Cendón, D.I., Pérez-Valera, F., 2014. Sulfate Isotope composition $\left(\delta^{34} \mathrm{~S}, \delta^{18} \mathrm{O}\right)$ and strontium isotopic ratios $\left({ }^{87} \mathrm{Sr} /{ }^{86} \mathrm{Sr}\right)$ of Triassic evaporates in the Betic Cordillera (SE Spain). Rev. Soc. Geol. Espana 27 (1) 2255-1379.

Oyarzun, R., Doblas, M., López-Ruiz, J., Cebrá, J.M., 1997. Opening of the central Atlantic and asymmetric mantle upwelling phenomena: implications for long-lived magmatism in western North Africa and Europe. Geol 25 (8), 727-730.

Peréz, N.M., Nakai, S., Wakita, H., Albert-Bertrán, J.F., Redondo, R., 1996. Preliminary results of the ${ }^{3} \mathrm{He} /{ }^{4} \mathrm{He}$ isotopic ratios in terrestrial fluids from the Iberian peninsula: seismotectoonic and neotectonic implications. Geogaceta 20, 830-833.

Peinado, M., García Rayego, J.L., González Cárdenas, E., Ruiz Pulpón, Á.R., 2009. Itinerarios geográficos y paisajes por la provincia de Ciudad Real. Guía de salidas de campo del XXI Congreso de Geógrafos Españoles. Imprenta Provincial, Ciudad Real.

Poblete Piedrabuena, M.A., 1992. Las ultimas manifestaciones asociadas al vulcanismo del Campo de Calatrava (Ciudad Real): los manantiales termales. Cuadernos de Sección. Historia 20, 187-201 0212-6397.

Poblete Piedrabuena, M.A., 1997. Evolución y características geomorfológicas del sector central del Campo de Calatrava (Ciudad Real). In: García Rayego, J.L., González Cárdenas, E. (Eds.), Elementos del Medio Natural en la provincia de Ciudad Real. UCLM, Cuenca, pp. 131-159.

Poblete Piedrabuena, M.A., Beato Bergua, S., Marino Alfonso, J.L., 2016. Landforms in the Campo de Calatrava volcanic field (Ciudad real, Central Spain). J. Maps 271-279. https://doi.org/10.1080/17445647.2016.1195302.

Portero, J.M., Ramírez, J.I., Ancochea, E., Pérez González, A., 1984. Mapa Geológico de España 1:50.000 (Magna). Hoja 784 Ciudad Real I.G.M.E. pp. 101.

Salata, G.G., Roelke, L.A., Cifuentes, L.A., 2000. A rapid and precise method for measuring stable carbon isotope ratios of dissolved inorganic carbon. Mar. Chem. 69 (1-2), 153-161. https://doi.org/10.1016/S0304-4203(99)00102-4.

Sano, Y., Marty, B., 1995. Origin of carbon in fumarolic gas from island arcs. Chem. Geol. $119,265-274$.

Sano, Y., Williams, S.N., 1996. Fluxes of mantle and subducted carbon along convergent plate boundaries. Geophys. Res. Lett. 23, 2749-2752.

Stoppa, F., Schiazza, M., 2013. An overview of monogenetic carbonatitic magmatism from Uganda, Italy, China and Spain: volcanologic and geochemical features. J. S. Am. Earth Sci. 41, 140-159.

Stoppa, F., Rosatelli, G., Schiazza, M., Tranquilli, A., 2012. Hydrovolcanic vs magmatic processes in forming maars and associated pyroclasts: the Calatrava - Spain - case history. In: Stoppa, F. (Ed.), Updates in Volcanology - A Comprehensive Approach to Volcanological Problems, 3-26. 9. InTech Open Access Publisher, Janeza Trdine, Rijeka, Croatia, pp. 51000. https://doi.org/10.5772/25264. 978-953-307-434-4.

Stumm, W., Morgan, J.J., 1996. Aquatic Chemistry. Chemical Equilibrium and Rates in Natural Waters. John Wiley, New York.

Tassi, F., Fazi, S., Rossetti, S., Pratesi, P., Ceccotti, M., Cabassi, J., Capecchiacci, F., Venturi, S., Vaselli, O., 2018. The biogeochemical vertical structure renders a meromictic volcanic lake a trap for geogenic $\mathrm{CO}_{2}$ (Lake Averno, Italy). PLoS One 13 (3) e0193914. https://doi.org/10.1371/journal.pone.0193914.

Tassi, F., Fiebig, J., Vaselli, O., Nocentini, M., 2012. Origin of methane in fluid discharges from Italian volcanic and hydrothermal systems as inferred by the isotopic features and the chemical composition of light hydrocarbons. Chem. Geol. 310-311, 36-48.

Tassi, F., Montegrossi, G., Vaselli, O., 2004. etodologie di campionamento ed analisi in fase gassosa. CNR-IGG Firenze, Rapporto Interno 1/2004. Mpp. 17.

Tassi, F., Vaselli, O., Luchetti, G., Montegrossi, G., Minissale, A., 2008. Metodo per la determinazione dei gas disciolti in acque naturali. CNR-IGG Rapporto Interno n. 2/ 2008. pp. 10.

Tassi, F., Vaselli, O., Tedesco, D., Montegrossi, G., Darrah, T., Cuoco, E., Mapendano, M.Y., Poreda, R., Delgado Huertas, A., 2009. Water and gas chemistry at Lake Kivu (DRC): geochemical evidence of vertical and horizontal heterogeneities in a multibasin structure. Geochem. Geophys. Geosyst. 10 (2). https://doi.org/10.1029/ 
2008GC002191.

Tedesco, D., Tassi, F., Vaselli, O., Darrah, T., Poreda, R.J., Cuoco, E., Yalire, M.M., 2009. Gas isotopic signatures (He, $\mathrm{C}$ and $\mathrm{Ar}$ ) in the lake kivu region (western branch of the east african rift system): geodynamic and volcanological implications. J. Geophys. Res. 115, B01205. https://doi.org/10.1029/2008JB006227.

Vaselli, O., Bicocchi, G., Tassi, F., Montegrossi, G., Nisi, B., Lelli, M., Buccianti, A., 2009. Fluid geochemistry at Caprese Michelangelo (Arezzo, Tuscany): the " 0 " point. Ciudad de la Energia, Internal Report. pp. 35.

Vaselli, O., Cuccoli, F., Giannini, L., Nisi, B., Sermi, F., Tassi, F., Capecchiacci, F., Capannesi, L., Nocentini, M., 2012. Open-Path IR Laser Measurements, thermal imaging and fluid geochemistry in the Campo de Calatrava Volcanic Field. Ciudad de la Energia, Internal Report. pp. 79.

Vaselli, O., Nisi, B., Tassi, F., Giannini, L., Delgado Huertas, A., 2011. Water and gas geochemistry from the $\mathrm{CO}_{2}$-rich field of Campo de Calatrava (Castilla-La Mancha). Ciudad de la Energia, Internal Report. pp. 39.

Vaselli, O., Nisi, B., Tassi, F., Darrah, T., Bruno, J., Elio, J.M., Grandia, F., Perez del Villar, L., 2013. Gas discharges for continental Spain: geochemical and isotopic features. In: Goldschmidt 2013, pp. 25-30. August, Florence 0026-461X. https://doi.org/10. 1180/minmag.2013.077.5.22.

Vaselli, O., Tassi, F., Montegrossi, G., Capaccioni, B., Giannini, L., 2006. Sampling and analysis of volcanic gases. Acta Vulcanol. 18, 65-76.

Venturi, S., Tassi, F., Bicocchi, G., Cabassi, J., Capecchiacci, F., Capasso, G., Vaselli, O.,
Ricci, A., Grassa, F., 2017. Fractionation processes affecting the stable carbon isotope signature of thermal waters from hydrothermal/volcanic systems: the examples of Campi Flegrei and Vulcano Island (southern Italy). J. Volcanol. Geoth. Res. 345 46-57.

Whiticar, M.J., Suess, E., 1990. Hydrothermal hydrocarbon gases in the sediments of the king-george basin, bransfield strait, Antarctica. Appl. Geochem. 5, 135-147.

Wilhelm, E., Battino, R., Wilcock, R.J., 1977. Low-pressure solubility of gases in liquid water. Chem. Rev. 77, 219-262.

Wilson, M., Downes, H., 1991. Tertiary-Quaternary extension related alkaline magmatism in Western and Central Europe. J. Petrol. 32, 811-849.

Wilson, M., Patterson, R., 2001. Intraplate magmatism related to short wavelength convective instabilities in the upper mantle: evidence from the tertiary-quaternary volcanic province of western and central Europe. In: In: Ernst, R.E., Buchan, K.L. (Eds.), Mantle Plumes: Their Identification through Time 352. Geological Society of America Special Papers, pp. 37-58.

Wolery, T.W., Jarek, R.L., 2003. Software User's Manual. EQ3/6, Version 8.0. Sandia National Laboratories-US Department of Energy Report, pp. 376.

Yélamos, J.G., Redondo, E., Castro, F. Dr, Galván, A., Martínez-Rubio, J., Rebollo, L., Ruano, P., Senderos, A., Villarroya, F.I., 1999. Hidrogeoquímica y microbiología en Los Hervideros del Campo de Calatrava (Ciudad Real). Geogaceta 26, 115-118.

Zhang, J., Quay, P.D., Wilbur, D.O., 1995. Carbon isotope fractionation during gas-water exchange and dissolution of $\mathrm{CO}_{2}$. Geochem. Cosmochim. Acta 59 (1), 107-114. 